Boise State University

ScholarWorks

Geosciences Faculty Publications and

Presentations

Department of Geosciences

4-15-2013

\title{
A Latest Carboniferous Warming Spike Recorded by a Fusulinid- Rich Bioherm in Timor Leste: Implications for East Gondwana Deglaciation
}

\author{
Vladimir I. Davydov \\ Boise State University \\ David W. Haig \\ University of Western Australia \\ Eujay McCartain \\ University of Western Australia
}

NOTICE: this is the author's version of a work that was accepted for publication in Palaeogeography,

Palaeoclimatology, Palaeoecology. Changes resulting from the publishing process, such as peer review, editing, corrections, structural formatting, and other quality control mechanisms may not be reflected in this document. Changes may have been made to this work since it was submitted for publication. A definitive version was subsequently published in Palaeogeography, Palaeoclimatology, Palaeoecology, (2013). DOI: 10.1016/ j.palaeo.2013.01.022 


\title{
A Latest Carboniferous Warming Spike Recorded by a Fusulinid- Rich Bioherm in Timor Leste: Implications for East Gondwana Deglaciation
}

\author{
Vladimir I. Davydov \\ Boise State University \\ David W. Haig and Eujay McCartain \\ University of Western Australia
}

\begin{abstract}
During the late Paleozoic and early Mesozoic Timor lay in the northern part of the north-south East Gondwana rift system along which the western margin of Australia later developed. Discovery of a latest Gzhelian bioherm in the central highlands of Timor Leste has implications for latest Carboniferous - earliest Permian climate history and deglaciation in basins further south in the rift system.

Limestone outcrop of the Maubisse Formation near the village of Kulau is recognized as a bioherm with a massive lower unit, including reef framework at the base, and a bedded grainstone upper unit. The bioherm developed on a basalt substrate in warm shallowwater, as indicated by photozoan assemblages in the massive lower unit. Foraminifera belonging to 17 genera are recorded from the bioherm. These include representatives of the families Biseriamminidae, Biwaellidae, Bradyinidae, Cornuspiridae, Lasiodiscidae, Palaeotextulariidae, Pseudotaxidae, Ozawainellidae, Schubertellidae, Schwagerinidae, Staffellidae and Textrataxidae. Twenty-one species have been referred to known types and 12 species are left in open nomenclature. The assemblage probably belongs within the uppermost Gzhelian Schwagerina robusta-Ultradaixina bosbytauensis Zone although a possible lowest Asselian correlation cannot be excluded. The bioherm is the oldest carbonate unit so far recorded from the Maubisse Formation, and the oldest sedimentary unit biostratigraphically dated in Timor.
\end{abstract}

The dominantly heterozoan composition of the skeletal component of the limestone (except for the basal photozoan assemblage) and the taxonomic diversity of the larger foraminifera suggest a subtropical environment consistent with a palaeolatitude of about $40^{\circ} \mathrm{S}$. The late Pennsylvanian was a time of glaciation that in Australia is represented by a significant stratigraphic hiatus in basins to the south of Timor in the East Gondwana rift system. The development of the Kulau bioherm during the latest Gzhelian may have coincided with a global warming spike that led to rapid melting of continental ice sheets and a substantial influx of glacigene sediment (alternating diamictite and mudstone) in the southern basins.

Key-words: Carboniferous-Permian transition, foraminifera, biostratigraphy, climate, Timor-Australia, late Paleozoic glaciation

\section{Introduction}

Figure 1. Position of Timor within the East Gondwana rift system (modified from Harrowfield et al., 2005). Within the interior-rift system, dash lines indicate positions of rifts during final continental breakup (at $155 \mathrm{Ma}$ in the vicinity of Timor; 136 Ma off southwest Australia; Heine and Müller, 2005). Rifting along the Meso-Tethyan ocean boundary started during the Early Permian (Metcalfe, 2006). Palaeolatitudes follow Li and Powell (2001).

During the late Mississippian to Early Permian vast ice sheets extended over much of high-latitude Gondwana (Isbell et al., 2003; Fielding et al., 2008). Within Gondwanan intracratonic depressions away from coeval orogenic belts Pennyslvanian deposits are poorly known and restricted in occurrence, whereas Asselian (earliest Permian) glacially influenced strata are widespread and thick indicating rapid influx of glacigene sediment during episodes of climate amelioration (Wopfner, 1999). In eastern Gondwana, these intracratonic strata were deposited in a broad north-south system of rifts together forming the East Gondwana rift system (Harrowfield et al., 2005; Ali et al., 2012; Western Australian Trough of Wopfner, 1999), along which Late Jurassic-Early 
NOTICE: this is the author's version of a work that was accepted for publication in Palaeogeography, Palaeoclimatology, Palaeoecology. Changes resulting from the publishing process, such as peer review, editing, corrections, structural formatting, and other quality control mechanisms may not be reflected in this document. Changes may have been made to this work since it was submitted for publication. A definitive version was subsequently published in Palaeogeography, Palaeoclimatology, Palaeoecology, (2013). DOI: 10.1016/j.palaeo.2013.01.022

Cretaceous continental breakup took place (Heine and Müller, 2005). Within the East Gondwana rift system, lowest Permian and uppermost Carboniferous deposits are known from Timor in the north (about $40^{\circ} \mathrm{S}$ ) and can be traced to the south through the Bonaparte, Canning, Carnarvon, and Perth Basins (about $60^{\circ} \mathrm{S}$ ) with decreasing marine influence (Fig. 1; Charlton et al., 2002; Gorter et al., 2005; Hocking et al., 1987; Mory and Beere, 1988; Mory et al., 2008; Playford et al., 1976). The Timor succession has been affected by Neogene orogeny (Keep and Haig, 2010; Audley-Charles, 2011; Haig, 2012), whereas the west Australian basins remain relatively undeformed.

While Charlton et al. (2002, table 1), in a review of the Timor Permian, could not confirm stratigraphic levels lower than the Sakmarian (Tastubian Substage), the description by Nogami (1963) of the fusulinid foraminifera "Triticites sp. indet." with a suggested earliest Permian age raised the possibility of Asselian or uppermost Pennsylvanian marine deposits in Timor. Fusulinids were elements of warm-water photozoan faunas during the Permian and are absent from cold-water carbonates composed of heterozoan facies (James, 1997). Besides the fusulinid assemblage from close to the Permian-Carboniferous boundary, younger Permian low diversity fusulinid faunas have been recorded from Timor (Schubert, 1915; Thompson, 1949; Gageonnet and Lemoine, 1958, photo 15; Nogami, 1963; Whittaker in Charlton et al., 2002).

Putting aside the misidentification of fusulinids in the Canning Basin by Chapman and Parr (1937; see Crespin, 1958; confirmed by Haig's re-examination of the original slides), no fusulinid foraminifera have been found in basins of the East Gondwana rift system south of Timor (Fig. 1). This probably reflects (1) northward increasing water temperatures over the $20^{\circ}$ of palaeolatitude between the southern extent of marine deposition in the Perth Basin and Timor (Fig. 1), and (2) the southward increasingly more restricted conditions within the interior sea. If the presence of warm-water faunal elements within the Asselian or uppermost Pennsylvanian in Timor was confirmed, correlation could be made with the known rapid increase in sedimentation derived from melting ice in the west Australian basins (Mory et al., 2008). More detailed analysis of the Timor fauna, may also determine if its stratigraphic level coincides with the Gzhelian maxima for late Paleozoic tropical fusulinid diversity (Groves and Lee 2008; Davydov et al. 2012) and thus a potential global warming episode (Mayhew et al., 2012). A coincidence of these records could point to a warm spike that may have initiated of the onset of the late Palaeozoic deglaciation in the East Gondwana rift system and elsewhere in Gondwana.

Unfortunately Nogami (1963) only broadly specified the locality of "Triticites sp. indet." near Hato Builico in Timor Leste. His material included a few poorly preserved specimens from a bedded, white limestone with calcareous algae and bryozoa. At outcrops in the Aileu-Maubisse region near the village of Kulau about $10 \mathrm{~km}$ north of Hato Builico, we found fusulinid-bearing limestone containing many representatives of a species closely resembling Nogami's "Triticites sp. indet." (here referred to Schwagerina gracilis Sjomina) associated with other fusuline species of Eostaffella, Reitlingerina, Parastallella, Schubertella, Biwaella, Schellwienia, and Schwagerina as well as with the smaller foraminifera Endotaxis, Tetrataxis, Calcivertella, Bradyina, Globivalvulina, Palaeotextularia, Monogenerina, Climacammina, and Deckerella. The taxonomy of the fauna will be published in a separate paper. Here the Kulau fauna and the geological setting are described followed by a discussion concerning the age and palaeoenvironment significance of this fauna. This information will enable stratigraphic correlation both to the south within the East Gondwana rift system and to other sites elsewhere in both the palaeo-southern and palaeo-northern hemispheres. It will also permit a broader appreciation of palaeogeography and climate shifts during the latest Carboniferous and earliest Permian in this region.

\section{Location and Geologic setting}

Figure 2. STRM image of Timor (compiled from NASA US Shuttle Radar Topography Mission images) showing the location of the Kulau study site. The insert map shows Timor as part of the non-volcanic Outer Banda Arc.

Figure 3. Map of Timor showing extent of Gondwana Megasequence (including the Maubisse Group) and the outcrop at Kulau. Insert image A is an aerial photograph of the Kulau area; image B is an enlarged view showing the extent of the studied bioherm.

Table 1: Locality co-ordinates and description.

The studied locality, at about $8.816^{\circ} \mathrm{S}, 125.547^{\circ} \mathrm{E}$ (Table 1 ), is situated in a broad belt of outcrop in the central highlands of Timor Leste that Audley-Charles (1968) mapped as the Maubisse Formation (Fig. 2). Gageonnet and Lemoine (1958) originally included this formation as the upper part of their "Maubisse Series" and they recognized that the metamorphosed lower part of the series (included as part of the Aileu Formation by AudleyCharles, 1968) graded upward into less diagenetically altered strata. With limited chronostratigraphic control, 
Audley-Charles (1968) suggested that the Maubisse Formation consisted of a lower part dominated by fossiliferous bedded limestone with some interbeds of eruptive and reworked eruptive rocks and a thick upper unit of "basic eruptive rocks". He placed the formation among "allochthonous" units of Asian derivation, and contrasted it with Gageonnet and Lemoine's (1958) "Cribas Series" (including the dominantly siliciclastic Atahoc Formation and overlying Cribas Formation as defined by Audley-Charles, 1968) that he regarded as "autochthonous" of Australian derivation.

Since then, the palaeomagnetic results of Chamalaun (1977a,b) and a better understanding of the biogeography of the Permian fauna in Timor (Archbold and Barkham, 1989; Archbold and Bird, 1989; Charlton et al., 2002) and of the tectonic assembly of South-East Asia (Hall, 2011) has led to a consensus that all the Permian strata of Timor are of Gondwanan affinity and were probably derived from the pre-breakup East Gondwana rift system. There is disagreement about whether at least some of the Timor Permian may have rifted away from the Australian margin during Late Jurassic continental breakup and later became emplaced again on the continental margin (in the Timor orogen) during the late Neogene (for example, see alternate pre-collision scenarios by Keep and Haig, 2010, and Audley-Charles, 2011).

The belt of Maubisse Formation in which the studied locality lies also includes the type area of the formation at Fatu Rabi to the west of Maubisse. As well as Maubisse Formation strata this belt is now recognized as also including other units, for example outcrops better assigned to the Atahoc and Cribas Formations as well as to the Triassic Aitutu Formation (Grady and Berry, 1977; Hunter, in an unpublished thesis cited in Charlton et al., 2002; and unpublished work by the present authors). The association of Permian lithofacies in the region suggests that the carbonate-dominated and volcanic-dominated units (characterised by Audley-Charles, 1968, as the Maubisse Formation) interdigitate with siliciclastic units best placed in the Atahoc and Cribas Formations as also suggested by Grady and Berry (1977) in East Timor and by Barkham in West Timor (in an unpublished thesis noted by Charlton et al., 2002). Contrary to the schematic stratigraphic chart of Charlton et al. (2002, fig. 3 ), there is no continuous limestone succession through the Permian in Timor. Rather isolated large lensoid bodies of limestone (mainly medium to thick bedded but in some places with small areas of reef framework) are observed in stratigraphic contact with volcanic or siliciclastic successions. Although the stratigraphic positions of most of these limestone bodies has yet to be precisely determined, our continuing work suggests that they range from at least the Gzhelian (latest Carboniferous) to the Lopingian (Late Permian).

The studied bioherm, located about 6 kilometers WNW of Maubisse (Fig. 2) near the village of Kulau, is structurally tilted with an almost continuous along-strike exposure of over $400 \mathrm{~m}$ (Fig. 3). Exposures of the bioherm include fresh outcrop at locality 6 in the Slokaka River, hill-side cliff exposures at localities 3 and 5 , and relatively flat easily accessible outcrop adjacent a 4WD track at locality 2 (Fig. 3). Each of these outcrops offers different insights into the nature of the build-up (see section 4). An additional fusulinid-bearing limestone was documented roughly $6 \mathrm{~km} \mathrm{SSE}$ of the studied bioherm. This locality (7) is in the Oharaikiik River area to the west of the Maubisse-Same road on the northern side of the dividing range between the Maubisse and Wailuli Valleys (see Table 1 for coordinates).

Detailed mapping has not been done in the general vicinity of the uppermost Carboniferous bioherm documented here. Along the Slokaka River (Fig. 3) and in nearby rivers and hills, exposures are dominated by uppermost Carboniferous to Permian strata including basalt flows, reworked volcanic sandstone and conglomerate, siliciclastic sandstone and mudstone, and lensoidal limestone build-ups. The outcropping strata in this area are attributed to the Maubisse, Atahoc and Cribas Formations.

\section{Material and Methods}

As part of a study to reconstruct the Gondwana stratigraphy of the structurally complex Timor orogenic belt, McCartain undertook reconnaissance sampling in the study region. Field examination and acetate peels of some of the limestone samples revealed fusulinid assemblages. Thin sections were prepared from these samples and examined by Davydov who identified assemblages of latest Carboniferous and/or earliest Permian affinity. McCartain and Haig returned to the area and measured a stratigraphic section and systematically sampled the strata (Table 1). Acetate peels were prepared from each sample and used to describe the microfacies and to identify the levels containing fusulinids. Grain counts were made from acetate peels onto which $>100$ points in a random grid had been drawn. Grains falling below the grid points were counted. Fusulinid-bearing samples were sent to Davydov who prepared oriented thin sections of individual specimens that allowed taxonomic discrimination of species following methods described by Rauser-Chernousova and Fursenko (1937) and Needham (1937). 
For preparation of acetate peels each limestone sample was slabbed and the cut surface etched in $2 \% \mathrm{HCl}$ acid for 3-4 minutes. The etched surface was flooded with acetone and a $\sim 0.1 \mathrm{~mm}$ thick sheet of acetate film was placed on the wet surface. After about two minutes when the acetone had dried and the film surface reset to form a mould of the surface, the peel was removed and placed under a heavy weight. Acetate peels allow rapid microscopic examination of large sections of rock. The procedure can be carried out in a field base camp. Clasts and structures that may be missed in smaller thin sections of the rock may be apparent in the peel.

Studied rock samples and acetate peels are housed in the collections of the Earth Science Museum at the University of Western Australia (Table 1). Thin sections containing the figured specimens of fusulinids are housed in the University of Iowa Paleontology Repository, USA (coll. SUI 132435-132595)

\section{Stratigraphic Section}

Figure 4. Stratigraphic log of the studied bioherm.

Figure 5. Massive limestone unit (MLU). A, contact between vesicular basalt and overlying reef-framework limestone (MPSU), locality 6. B, lowest part of MLU, showing framework of aborescent algae(?) and colonial rugose corals (MPSU), locality 6. C, lower part of MLU showing large gastropods and coral fragments with a framework of arborescent algae(?) (MPSU), locality 6. D, lower part of MLU showing branching corallum with large diameter corallites (MPSU), locality 6. E, cliff section at locality 4 with massive limestone unit (MLU) overlain by bedded grainstone unit (BGU). F, massive limestone unit at locality 2 showing karstic weathering. G. base of massive limestone unit at locality 6 showing -lens $\|$ of limestone within basalt below the main contact with MLU where person is sitting.

Figure 6. Bedded grainstone unit (BGU). A, BGU in river at locality 6. B, Enlarged view of outcrop at locality 6 showing bedding pattern. C. Cliff face outcrop at locality 5 showing lower beds of BGU. D, BGU at locality 2 showing interbedded friable red mudstone.

Table 2. Grain constituents in studied samples from the Kulau bioherm.

The studied bioherm is divided into several units (Fig. 4). At the base, overlying vesicular basalt (Fig. 5) is a massive limestone unit (MLU) that in turn is overlain by a bedded grainstone unit (BGU; Fig. 6). The base of the siliciclastic mudstone unit (SMU) marks the top of the bioherm. MLU is further divided into a massive photozoan subunit (MPSU) at the base gradationally passing upward into a massive heterozoan subunit (MHSU). Different biogenic constituents distinguish the subunits, although the boundary between these has not been precisely defined. MLU exhibits karstic weathering at locality 2 (Fig. 5F), whereas BGU is exposed in continuous outcrop along a 4WD track to Kulau village. From the cliff outcrops between localities 3 and 5 (Fig. 3 ) it is evident that MLU varies in thickness laterally from about $9 \mathrm{~m}$ at locality 2 to $24 \mathrm{~m}$ at localities 4 and 5 . The cliff exposure also displays a possible syn-sedimentary fault with MLU thickening substantially across the high-angle fault. On the thickened side of the fault a $\sim 50 \mathrm{~cm}$-thick pebbly conglomerate comprising reworked volcanic sediment subdivides MLU. Although not investigated in detail, BGU apparently remains relatively constant in thickness $(\sim 9 \mathrm{~m})$ along the lateral extent of the cliff.

The outcrop at location 6 in the Slokaka River (Fig. 3) includes fresh exposures of the vesicular basalt and MLU and the contact between these (Fig 5A). No obvious cooling margins are evident at the contact which together with the vesicular nature of the basalt suggests the basalt is extrusive rather than intrusive. Just below the main contact the basalt includes 'lenses' of massive limestone (Fig. 5G) of uncertain origin. In the river outcrop the framework forming the base of the massive limestone includes arborescent probable algae (Fig. 5b) and colonial rugose corals (Figs 5a-d). Fresh exposure of BGU (Fig. 6A) is present in the river, with good exposures of sedimentary structures, stratigraphically above the massive limestone but the contact between these units is obscured by scree and river sand. In contrast to locality 2 where SMU overlies BGU, at locality 6 possible volcaniclastic strata with limestone 'lenses' overlie BGU. It remains uncertain if this difference between localities is due to a faulted contact at locality 6 or represents lateral facies variation across the study area.

At the base of the section, rudstone matrix from MPSU includes abundant tubiphytes (29-68\% of grains), common to abundant foraminifera (8-62\%), common crinoid plates (3-30\%), and in approximate order of abundance and persistance generally rare fragments of brachiopods, bryozoans, dasycladacean algae, skeletal cyanobacteria, ostracods, gastropods, rugose corals and echinoid spines (Table 2). Encrusters like tubiphytes and calcitornellid foraminifera are attached to many of the crinoid columnals. The grain assemblage of the overlying MHSU is dominated by crinoid debris (50\%) and bryozoan fragments (48\%) and includes very rare foraminifera, brachiopod fragments, rugose corals, echinoid spines, possible phylloid algae (? Anchicodium), and solenoporacean algae (Table 2). MLU cement types include syntaxial cement around crinoid plates and interparticle granular cements. There is evidence of recrystallization of bioclasts in some samples and some of 
the cement may be neomorphic. Throughout MLU the grains exhibit little evidence of microboring or micritization.

Grain assemblages of beds (10-60 cm thick) within the BGU comprise mainly bryozoan fragments (47-86\% of grains) and crinoid debris (14-51\%) along with very rare foraminifera (mainly tetrataxids), brachiopod fragments, ostracod carapaces, and rugose corallites (Table 2). Several beds are strongly dolomitized. There is little evidence of microboring or micritization of grains. Syntaxial cement is common around crinoid plates and in some beds grains are in stylolitic contact with concentrations of ferruginous material along the seams enhancing the red colour of the rock. Weakly planar laminated non-calcareous mudstone of SMU overlies BGU. SMU is sparsely fossiliferous with rare small solitary rugose corals, brachiopods, bryozoa and crinoids found at some levels.

The thickness variations of MLU described above suggest that this limestone succession including the BGU is probably lensoid in architecture and may be classified as a bioherm according to the original definition of Cummings (1932). It also fits into the spectrum of reef structures described by James and Wood (2010). While tubiphytes, calcareous algae, and colonial rugose corals at the base of the MLU (i.e. the MPSU) established a lensoidal core this geometry was maintained throughout deposition of the upper MLU (i.e. the MHSU) and BGU. The coeval surrounding "basinal" units have not been studied in this area but elsewhere in the Maubisse area basinal strata adjacent other lensoid buildups comprise beds of limestone with transported crinoidal and bryozoan debris interbedded with siliciclastic mudstone.

No detailed stratigraphic work has been done at locality 7 where a fusulinid assemblage similar to that within MPSU was documented in a structurally complex area. The fusulinid assemblage (from sample 144397; Tables 1,3 ) comes from a medium-bedded limestone rich in volcanic clasts with thick successions of bedded to massive fossiliferous limestone in the vicinity.

\section{Fusulinid assemblages composition and age assignment}

Table 3: Distribution of foraminifera and algae in studied samples

Relatively diverse assemblages belonging to the foraminiferal families Biseriamminidae, Biwaellidae, Bradyinidae, Cornuspiridae, Lasiodiscidae, Palaeotextulariidae, Pseudotaxidae, Ozawainellidae, Schubertellidae, Schwagerinidae, Staffelidae and Tetrataxidae were recovered from 12 samples in the bioherm and from sample 144397, locality 7 (Table 3). The taxonomic composition is similar in all samples from MPSU suggesting that these are probably of similar age. The overlying assemblage from 158153 (MHSU) is less diverse as is the fauna from 144397 at locality 7 (Table 3). In BGU, only very rare tetrataxids were noted.

For age determination, the smaller foraminifera (e.g. Biseriamminidae, Bradyinidae, Cornuspiridae, Palaeotextulariidae, Pseudotaxidae, and Tetrataxidae) include long ranging taxa that are of little help for precise chronostratigraphic correlation. Among the other foraminifera found in the Kulau section, the schwagerinid species (Table 3) are most diagnostic for age. Commonly occurring Schellwienia klunnikovi, Sch. malkovskyi, Sch. modesta and Sch. porrecta are typical late Gzhelian species. S. klunnikovi was described from the Pseudofusulina elegans zone in Darvaz which is equivalent to the upper Gzhelian Daixina sokensis zone on the Russian Platform (Davydov, 1986a,b). Schellwienia malkovskyi, Sch. modesta and Sch. porrecta were described from PreCaspian and Russian Platform deposits that were originally correlated with the Lower Permian (Kireeva et al., 1971), but have been shown to range down into the pre-Asselian (Davydov et al., 1992). These species have been found in the upper Gzhelian Daixina sokensis zone and uppermost Gzhelian Schwagerina robusta-Ultradaixina bosbytauensis zone in Darvaz, Central Asia, Southern Urals, Donets Basin, Iran, Carnic Alps, Greenland and Spitsbergen (Davydov, 1986a,b, 1992; Davydov and Kozur, 1997; Nilsson and Davydov, 1997; Forke et al., 1998; Davydov et al., 2001; Leven and Gorgij, 2006).

Schwagerina gracilis, Schw. vozhgalensis and Schw. pomposa were originally described from Russian Platform deposits that were then correlated with the Asselian, Lower Permian (Rauser-Chernousova and Shcherbovich, 1958; Sjomina, 1961; Kireeva et al., 1971), because of the confusion with the position of the CarboniferousPermian boundary (Davydov et al., 1992). When the boundary position was permanently established in the Global Time Scale (Davydov et al., 1998) these rocks were assigned to the latest Gzhelian. The upper range (LAD) of these species in the Donets Basin and Southern and Central Urals is early Asselian (Davydov, 1986a, 1992; Vilesov, 2000). 
Schwagerina subrobusta has been described in Darvaz from the Pseudofusulina elegans zone in the same beds where Schellwienia klunnikovi, Sch. malkovskyi, Sch. modesta and Sch. porrecta were found (Davydov, 1986b). Schwagerina biangpingensis has been described from the "Pseudoschwagerina uddeni" zone spanning the Carboniferous-Permian boundary (see Appendix 1) in one of the most important boundary sections in China, the Biangping reference section at Houchang, Guizhou, South China (Xiao et al., 1986). Unfortunately, the precise range of the species has not been determined.

Based on all the distributions discussed for the Biangping section (Appendix 1), the fusulinids from Timor belong within the upper Gzhelian Daixina sokensis zone through lower Asselian Sphaeroschwagerina vulgaris $-S$. fusiformis zone. However, the species characteristic of the upper Gzhelian Daixina sokensis zone (Schellwienia klunnikovi, Sch. malkovskyi, Sch. modesta, Sch. porrecta and Schwagerina subrobusta) and those that range into the uppermost Gzhelian Schwagerina robusta-Ultradaixina bosbytauensis zone are relatively rare in the Timor succession. The most abundant species in the Timor samples are Schwagerina gracilis, Schw. vozhgalensis and Schw. pomposa. Their acme in successions in the Russian Platform, Urals, Spitsbergen and Central Asia is in the uppermost Gzhelian Schwagerina robusta-Ultradaixina bosbytauensis zone. They are very rare in the lower Asselian Sphaeroschwagerina vulgaris -S. fusiformis zone. Thus, the assemblage from studied samples most probably belongs within the uppermost Gzhelian Schwagerina robusta-Ultradaixina bosbytauensis zone, a correlation that is consistent with the data from South China (see Appendix 1). Nevertheless, taking into account the remote location of Timor with regards to the Russian Platform and the Urals, an earliest Asselian age cannot be entirely excluded.

Although less well known, stratigraphic ranges of the species of Eostaffella, Schubertella, and Biwaella (as discussed by Dunbar and Skinner, 1937; Rauser-Chernousova et al., 1951; Davydov, 1984, 2011; Ross, 1995; Leven and Taheri, 2003; Leven, 1997; Maslo and Vachard, 1997) are consistent with a latest Gzhelian age for the studied Timor fauna.

\subsection{Depositional Model}

A detailed facies analysis is beyond the scope of this paper. Instead sediment composition, microfacies and sedimentary structures are used to develop a depositional history for the bioherm.

The base of MLU represents the initiation of the bioherm, the position of which is likely to have been controlled by the underlying thick succession of basalt (possibly 200m thick) resulting in a basinal high with a stable substrate. The base is interpreted to represent the shallowest facies during bioherm development, occurring well within the photic zone of a subtropical shallow sea. Although photozoan elements such as larger foraminifera (fusulinids), colonial rugose corals (Fig. 5a-d), arborescent probable algae (Fig. 5b), and tubiphytes are present (Table 2), the rarity of dasycladacean algae, the lack of microborings and micritization of grains (although encrustations by tubiphytes and calcitornellid foraminifera are in places common), and the relatively low diversity of fusulinids suggest that water temperatures were warm temperate rather than fully tropical. Deposition was most likely initiated high in the photic zone in the warmest waters above storm-weather wave base and possibly above fair-weather wave base (with wave energy moderate because of the intracratonic setting).

As MLU developed the photozoan sediment components became rare and bryozoan and crinoidal debris became dominant. The sediment of MHSU is typical of a late Palaeozoic heterozoan assemblage (James 1997). This change from a marginal photozoan to a heterozoan biota may reflect both a slight increase in water depth as well as a decrease in water temperatures with deposition now occurring within the photic zone likely below fairweather wave base. The rather monotonous succession of the same facies suggests the bioherm was within a keep-up phase of growth during deposition of this unit.

Within BGU the terminal phase of bioherm development was initiated by the encroachment of red noncalcareous mudstone. The mudstone (including possible ash) occurs as laminae to thin beds within thin to medium beds of grainstone (Figs 6a-e). This sediment heterogeneity highlights sedimentary structures including wavy laminae and flaser bedding (Fig. 6e) indicative of wave and possible tidal currents likely below fairweather wave base. Biotically this unit is very similar to, if not the same as, MHSU in that crinoidal and bryozoan debris dominate the grain assemblage. Deposition took place in similar water temperatures to those represented by MHSU. The base of the SMU represents termination of bioherm development. SMU is a friable mud unit that is poorly exposed and has not been investigated during this study. 


\subsection{Biogeographic and Palaeoclimate Implications}

Figure 7: Late Gzhelian-early Asselian paleogeography (from Blakey, http://jan.ucc.nau.edu/rcb7/mollglobe.html with slight modifications) showing distribution of buildups; highly diverse tropical fusulinid and less diverse temperate (Schellwienia-Schwagerina dominated) faunas. 1, Texas, New-Mexico and Arizona; 2, North America Great Basin; 3, McCloud; 4, Yukon, Alaska; 5, Canadian Arctic; 6, Spitsbergen and Barents Sea; 7, Timan-Pechora; 8, Russian Platfortm and Southern_Urals; 9, Donets Basin; 10, Pre-Caspian; 11, Central_Asia; 12, Carnic_Alps; 13, North_China; 14, South_China; 15, Central Iran, Sanandaj-Sirjan Zone; 16, Yunnan (Sibumasu); 17, Timor

Late Paleozoic fusulinids were distributed in the tropical-subtropical belt (up to $35-40^{\circ} \mathrm{S} / \mathrm{N}$ palaeolatitude) within carbonate to mixed carbonate-siliciclastic shallow-water settings (Ross, 1995; Kobayashi and Ishii, 2003). Based on similarities with size, test morphology and with the biofacies associations of modern larger benthic foraminifera (Beavington-Penney and Racey, 2004; Hohenegger, 2004; Murray, 2006) the fusulinids are assumed to have hosted photosynthetic symbionts (Ross, 1982; Vachard et al., 2004; BouDagher-Fadel, 2008). Temperature and light availability are the most important factors controlling the distributions of larger symbiont-bearing foraminifera in seas of normal salinity. Shallow-water assemblages of present-day larger foraminifera in optimal water temperatures $\left(20-30^{\circ} \mathrm{C}\right)$ generally are much more diverse than those in temperatures greater than $30^{\circ} \mathrm{C}$ or less than $20^{\circ} \mathrm{C}$. (Beavington-Penney and Racey, 2004; Hohenegger, 2004; Murray, 2006). Similar changes in diversity are apparent in the latitudinal distribution of the late Paleozoic fusulinids and these are assumed to correspond to tropical-subtropical temperature changes (Ross, 1995; Ross and Ross, 1995).

During global warm episodes larger symbiont-bearing foraminifera could migrate to higher latitudes. By contrast, cooling led to emigration of parts of the foraminiferal fauna from higher to lower latitudes, stepwise extinction of some of the larger taxa, increasing provincialism and the preferential survival of faunas adapted for a broader range of facies (Stanley, 1984; Kalvoda, 2002; Mayhew et al., 2012). Mid-latitudes are the areas where climatic fluctuations and velocity of climate change are most significant as has been shown in modernworld (Burrows et al., 2011) and Permian models (Winguth et al., 2002). Fusulinid faunas provide a particularly sensitive index of climate change in these mid-latitude regions. In late Palaeozoic continental reconstructions (e.g. Ziegler et al., 1997), such transitional areas include BolivialPeru, Oman, Central Iran (Pusht-e-Badam block only), Central and South-East Pamirs, Salt-Range, Timor and other regions in the Neo-Tethys as well as localities on the northern margins of Pangaea (Russian and Norwegian Arctic, Wrangel Island, North Greenland, Sverdrup Basin in Canada,).

The Late Carboniferous to Early Permian continental glaciation-deglaciation cycles would have had a significant impact on the distributions of fusulinid foraminifera in the mid-latitudinal zone. Permian climate simulation models (Winguth et al., 2002) suggest a significant 5-7 $\mathrm{C}^{\circ}$ latitudinal shift in average sea-surface temperature and associated climatic belts under glacial versus non-glacial (warm) climate states. The latest Gzhelian to earliest Asselian interval included (1) the highest peak in fusulinid diversity within the Pennsylvanian-Cisuralian interval (Groves and Lee, 2008; Davydov et al., 2012); (2) a major marine transgression documented in many regions in Northern Pangaea (Davydov, 1984; Davydov et al., 2003; Leven and Gorgji, 2006; Ehrenberg et al., 2000); and (3) the occurrence of fusulinids in many mid-latitudinal areas including the present record in Timor (Figure 10). The coincidence of these features suggests that a sharp warming episode took place close to the Carboniferous-Permian transition.

The occurrence of an uppermost Gzhelian bioherm in Timor is consistent with the global distribution pattern of reefs at this time as documented by Wahlman (2002). The late Gzhelian-early Asselian in Northern Pangaea was a time of major reef development (Figure 8). Very large buildups have been reported in the upper Gzhelianlower Asselian in the Urals (Chuvashov, 1984), Canadian Arctic (Beauchamp, 1993), eastern Idaho (Breuninger, 1976), the McCloud Limestone in Panthalassa, California (zone A; Watkins and Wilson, 1989), Barents Sea, Spitsbergen and Bear Island (Lonoy, 1988; Skaug et al., 1982; Samuelsberg et al., 2003; Stemmerik et al., 1994; Elvebakk, 2002), Texas and New Mexico (Wahlman, 2002), Carnic Alps (Krainer, 1995), Donets Basin and the Precaspian (Lukin and Galitskiy, 1974; Wahlman, 2002) and Central Asia (Khodjanyazova and Mamet, 2003; and personal data of VID).

During the late Gzhelian warming episode, the taxonomic expression of the foraminiferal families Fusulinida and Schwagerinida was different in the tropics and subtropics. In the western Tethys tropics (Donets Basin, S. Urals, Central Asia, Iran, Carnic Alps) the dominant genera were Dutkevitchia, Rugosofusulina, Ruzhenzevites, Praepseudofusulina, Ultradaixina, Likharevites and Rugosochusenella whereas Schellwienia and Schwagerina were relatively rare (Davydov and Kozur, 1997; Davydov, 1986a,b; Forke et al., 1998; Leven and Scherbovich, 1978; Leven and Gorgij, 2006, 2011). These occurrences contrast with those in Timor where Schellwienia and 
Schwagerina are dominant and the other genera among Schwagerinids have not been recorded. There were significant differences in the diversity of species and genera within the Fusulinida (except Schubertellidae) and Schwagerinida between the tropics and subtropics. For example in the Aidaralash section in the Southern Urals [the GSSP of the Carboniferous-Permian boundary, (Davydov et al., 1998)], which was at about $10^{\circ} \mathrm{N}$ during the late Gzhelian, 14 genera and

\begin{tabular}{|l|l|l|l|l|l|l|l|l|}
\hline \multicolumn{2}{|l|}{ Region } & \multicolumn{2}{l|}{ Age } & \multicolumn{2}{|l|}{ Aidaralash } & \multicolumn{2}{l|}{ Spitsbergen } & \multicolumn{2}{l|}{ Barents Sea } & \multicolumn{2}{l|}{ Timor } \\
\cline { 2 - 10 } & genus & species & genus & species & genus & species & genus & species \\
\hline Upper Gzh & 14 & 84 & 6 & 35 & 5 & 36 & 2 & 11 \\
\hline Lower As & 15 & 82 & 7 & 41 & 6 & 34 & & \\
\hline
\end{tabular}

84 species are present in the upper Gzhelian and 15 genera and 82 species occur in the lower Asselian (Davydov, 1986a; Schmitz and Davydov, 2012). At higher latitudes, approximately $30-35^{\circ} \mathrm{N}$, in the northern subtropics (Spitsbergen, Timan-Pechora, Barents Sea, Greenland and Canadian Arctic) Schellwienia and Schwagerina dominate in the upper Gzhelian through lower Asselian (Nilsson and Davydov, 1997; Davydov et al., 1999; Konovalova, 1991; Remizova, 1995; Volozhanina, 1963). In the upper Gzhelian of Spitsbergen (data from 8 sections, the Carboniferous-Permian transition characterized with 26 samples) 6 genera and 35 species are recognized (Nilsson and Davydov, 1997) and in coeval strata in the Barents Sea region (data from 6 wells, where the Carboniferous-Permian transition characterized with 29 samples), 5 genera and 36 species are recorded (Nilsson and Davydov, 1997 and personal unpublished data of VID). Similarly in the lower Asselian, there are 7 genera and 41 species in Spitsbergen and 6 genera and 34 species in the Barents Sea successions. In Timor, in the upper Gzhelian we found just 2 genera and 11 species of the larger foraminifera. Therefore Timor has the lowest diversity of the Fusulinida-Schwagerinida group in the upper Gzhelian compared to the other regions discussed above. This suggests that the climate was temperate-subtropical, similar to that in Northern Pangaea which is consistent with a palaeolatitude of $\sim 40^{\circ} \mathrm{S}$ in $\mathrm{Li}$ and Powell's (2001) reconstruction (Fig. 1). Timor may have been close to the southern limits of bioherm development during the latest Gzhelian and near the periphery of the habitation range of larger fusuline foraminifera.

\subsection{Correlations with adjacent Gondwanan blocks in South-East Asia}

Figure 8. Correlation chart comparing known faunas in Timor, Sarawak, Sumatra and Western Yunnan with the fusulinid zones and regional stages in the Urals.

From Cimmerian blocks that separated the East Gondwana rift system from the Tethyan Ocean, GzhelianAsselian glacigene deposits are known from Lhasa-Baoshan-Shan and Tengchong-Malay-Sumatra blocks (Wopfner, 1999). In these blocks Gzhelian-Asselian fusulinid-bearing limestone are present in Sumatra (Thompson, 1936; Fontaine and Vachard, 1984, 1986), Sarawak (Vachard, 1990) and western Yunnan (Chen Genbao et al., 1991; Jin, 1994; Ueno et al., 2003).

In Sumatra, Thompson (1936) described a small assemblage from Telok Gedang that included two new species. One of the new species, "Schwagerina rutschi", as noted by Thompson, (1936, p. 589) “...is somewhat intermediate between typical Triticites Girty and typical Schwagerina Moller, but it seems to be more closely related to the type of the latter genus, S. princeps (Ehrenberg), and hence I am referring it to Schwagerina". This species closely resembles Schwagerina pomposa, but possesses less well-developed septal fluting. The second species, "Pseudoschwagerina" meranginensis Thompson, belongs to Sphaeroschwagerina and is very similar to $S$. kolvica (Scherbovich) that is found in the lowermost Asselian in the Aidaralash section, southern Urals (Davydov, 1986a, pl. 14, fig 8). Also, this form could be Likharevites esetensis (Davydov), which is characteristic for uppermost Gzhelian in the Urals and Donets Basin (Davydov, 1986a, 1992). The exact taxonomy could be find out only after the additional study of Telok Gedang locality in Sumatra.

The "Asselian" fauna from Sumatra, reported by Fontaine and Vachard (1984, 1986), requires taxonomic revision using oriented sections in order to be confident about its age.

Fontaine (2002) and Hutchinson (2005) both cited the identifications of Cummings (1962) as evidence for Asselian fusulinids in Sarawak, Malaysia. Cummings (1962) identified "Pseudoschwagerina (Zellia) heritschi heritschi", "Pseudoschwagerina uber", "Paraschwagerina cf. gigantean" and "Schwagerina sp". Of these species Schwagerina sp., Pseudoschwagerina sp. and Paraschwagerina cf. gigantea (White) are similar small, 
juvenile schwagerinid specimens (about 1-2 $\mathrm{mm}$ in diameter) with fluted septae and relatively tight initial volutions. There are over a dozen genera that fit these features and they range from upper Pennsylvanian through Guadalupian. The form that was named as "Paraschwagerina (Zellia) cf. heritschi heritschi Kahler and Kahler" is also a very small schwagerinid (less than $1 \mathrm{~mm}$ long) and does not belong to Zellia. It could be a Darvasites, but as it is a juvenile form the precise taxonomy is not possible. The examples of "Nummulostegina cf. velebitana Schubert" identified by Cummings (1962) probably belong to the primitive boultoniid Boultonia ex gr. willsi Lee. Such forms are known to range from uppermost Gzhelian through Kungurian. Thus, none of the forms published by Cummings (1962) suggests a specific Asselian age, but rather a broad latest Carboniferous to Early Permian age.

A biozonation of the Upper Carboniferous to Lower Permian limestone succession in Sarawak was proposed by Vachard (1990). Two assemblages similar to those first reported by Sanderson (1966) were established for the Moscovian. Three zones were proposed in the uppermost Gzhelian to lower Asselian: (1) Dutkevitchites Zone, (2) Pseudofusulina-Nodosaria Zone and (3) Occidentoschwagerina Zone, although the taxonomy of some of the key species, and therefore age determinations, may require revision when oriented sections become available. A prominent Dutkevichites Davydov (1984) is known from Central Asia, Carnic Alps and Donets Basin within a very narrow stratigraphic range in the uppermost Gzhelian Ultradaixina bosbytauensis-Schwagerina robusta zone. Its occurrence in Sarawak indicates the presence of the uppermost Gzhelian.

A well documented fauna was described from Changning-Menglian Belt, West Yunnan (Ueno et al., 2003). The Ytz4 assemblage includes Schwagerina aff. robusta (=Schwagerina sphaeroidea by Ueno et al., 2003), Schellwienia klunnikovi (=Triticites noinskyi by Ueno et al., 2003), Ultradaixina (="Bosbitauella"of Ueno) sp. and Rugosochusenella pseudogregaria (Bensh), and clearly suggest that Ytz4 zone belongs to the uppermost Gzhelian. It is important to note the significantly higher diversity of the fusulinid assemblage from Yunnan compared with the assemblage from Timor and presence of typical tropical elements such as Ultradaixina.

\subsection{Correlations within the East Gondwana Rift System}

Figure 9. Correlation chart comparing the Timor succession with units known further south in the East Gondwana rift system. In Timor, the stratigraphy above the Gzhelian is schematic with precise positions of bioherms, bedded limestone and volcaniclastic units uncertain. In the Bonaparte, Canning, Southern Carnarvon, and Northern Perth Basins, the ages of the lower parts of the Kulshill Group, Grant Group, Lyons Group, and Nangetty Formation are uncertain but may range down into the Gzhelian (see discussion in 6.4).

Within remnants of the East Gondwana rift system (Fig. 1), coeval Gzhelian and Asselian successions are best known in Western Australian basins (Fig. 7) where they are represented by glacially influenced marine strata. From similar intracratonic basins in southern Gondwana, Gzhelian-Asselian glacigene deposits (including, for example, diamictites) are widespread in Antarctica, southern South America, southern Africa, the Arabian Peninsula, and the Indian subcontinent within the northern Gondwana (Wopfner, 1999; Fielding et al., 2008; Wopfner and Jin, 2009).

The glacially influenced successions found at the base of the Permian in these southern Gondwanan intracratonic basins belong to the spore-pollen Pseudoreticulatispora confluens Zone (also called the Granulatisporites confluens Zone or the Converrucosisporites confluens Zone) or to zones that are very close in composition to this oppel zone (Foster and Waterhouse, 1988; Mory and Backhouse, 1997; Backhouse, 1998; Eyles et al., 2002; Archbold et al., 2004; Stephenson, 2009; Mantle et al., 2010). The base and top of the $P$. confluens Zone are poorly constrained in terms of age. The top of the zone in the subsurface of the Perth Basin lies within the Holmwood Shale (Backhouse, 1998) that in outcrop at one level contains a monospecific ammonoid assemblage of Juresanites jacksoni (Etheridge). This is the lowest ammonoid-bearing horizon in the Permian of the Western Australian basins and has been attributed to the Tastubian (Lower Sakmarian; Glenister et al., 1973). The latter species, however, on the basis of evolutionary development is close similar to Juresanites kazakhorum (Ruzhenvzev) that is characteristic for Sterlitamakian in the Urals (Ruzhentsev, 1952; Leonova, 2011). The other ammonoids from middle-upper Holmwood Shale include Metalegoceras kayi, M. striatum, M. clarkei and Uraloceras irwinense (Skwarko, 1993). Boiko et al. (2008) considered Metalegoceras kayi being similar with M. gerassimovi from Sterlitamakian in the Urals. They included M. clarkei into new subgenus Atrtimetalegoceras that is ranging from late Sakmarian into Artinskian. Most likely entire Holmwood Shale correlates with upper Sakmarian or even lower Atinskian in the Urals. Recent study of upper Sakmarian and Artinskian deposits in Carnic Alps suggests that some "Sakmarian" ammonoids are actually Artinskian in age (Davydov et al., 2013). 
Although tentative correlations have been made to the Tastubian and Asselian based on rare components of the marine benthic macrofauna (e.g. Foster and Waterhouse, 1988; Archbold, 2001; Archbold et al., 2004) no definitive biostratigraphic age determinations exist for the base of the P. conflluens zone in Australian basins. Recent studies elsewhere in Gondwana (see below), suggest that the base of the $P$. confluens zone lies within the Upper Carboniferous. In the Ganigobis Shale Member of the Dwyka Group in Namibia, Stephenson (2009) recorded the presence of the $P$. confluens zone associated with ash beds radiometrically dated as latest Gzhelian or earliest Asselian, although these SHRIMP-based U/Pb dates (Bangert et al., 1999; Stollhofen et al., 2000) may have to be reassessed using more recent higher precision methods and standards. A series of Pennsylvanian high-resolution U-Pb dates from the Paganzo Group in Argentina (Gulbranson et al., 2010) included a $312.82 \pm$ $0.11 \mathrm{Ma}$ age (Moscovian) for the upper shallow-marine part of the Tupe Formation that contains the $P$. confluens zone (Vergel, 2008). As Stephenson (2009) pointed out, the base of the P. confluens Zone in Western Australian basins, which marks a huge influx of glacigene sediment, may be within the Late Carboniferous.

Definitive dating of the $P$. confluens zone, and thereby the Early Permian deglaciation succession, in Western Australian basins may depend in future on radiometric dating of ash horizons if these can be located. Volcanic sills are known from the Permian of the Canning Basin (Reeckmann and Mebberson, 1984), with a suggestion that doleritic sills as old as Asselian may be present. This volcanism correlates with that in the uppermost Carboniferous and Permian of Timor.

\subsection{Implications for deglaciation in East Gondwana rift system}

The high-latitude oxygen isotope trend, based on brachiopods and bivalves, established by Korte et al. (2008) for the Australian Permian presents only a Sakmarian and later record. This showed overall warming during the Early Permian until the Artinskian with a sea-surface temperature gradient of $9^{\circ}-12^{\circ} \mathrm{C}$ between tropicalsubtropical $\left(<30^{\circ} \mathrm{S}\right)$ and high southern latitude $\left(55 \pm 10^{\circ} \mathrm{S}\right)$ seas that was maintained throughout this period. This compares with a sea-surface temperature gradient of about $22^{\circ} \mathrm{C}$ in present-day oceans between equivalent latitudes. The Australian Permian measurements of Korte et al. (2008) came from shell assemblages that inhabited shallow intracratonic seas rather than an open ocean margin and this certainly would influence the seasurface temperatures. It seems reasonable to assume that during the Gzhelian-Asselian a temperature gradient of perhaps $5^{\circ} \mathrm{C}$ or more may have been present in the intracratonic shallow seas of the East Gondwana rift system between paleolatitudes of $40^{\circ} \mathrm{S}$ and $60^{\circ} \mathrm{S}$ (Fig. 1). Whereas subtropical bioherms may have formed on shallow platforms at around $40^{\circ} \mathrm{S}$ (as in Timor) in the more open northern parts of the rift system, further south where marine conditions were more restricted, lower sea-surface temperatures may have precluded the presence of biota producing photozoan skeletal assemblages. Warming pulses during deglaciation would be detected by immigrant species with warm-water affinities.

The Gzhelian bioherm found in Timor, in the northern part of the East Gondwana rift system, may be a product of a global warm spike (section 6.2). Conditions within the very shallow intracratonic sea to the south of Timor fluctuated in terms of nutrition, salinity, water depths, and temperature (Haig, 2003, 2004; Dixon and Haig, 2004). The marine stratigraphic record in the more southern basins consists mainly of sandstone/mudstone cycles with isolated beds in the succession containing shelly macrofauna that usually differs in composition from fossiliferous beds above and below. The exception, deposited at the end of the Early Permian deglaciation interval, is the Upper Sakmarian Callytharra Formation and its correlatives where fossiliferous limestone is present at the top of frequent sedimentary cycles (Dixon and Haig, 2004).

Within the basal glacially influenced deposits of the $P$. confluens Zone, shelly macrofaunal assemblages are rare and generally of low diversity (Skwarko, 1993). The deposits of this zone include large thicknesses of mudstone or sandstone alternating with diamictites (Condon, 1967; Eyles and Eyles, 2000; Eyles et al., 2003; Eyles et al., 2006). The stratigraphic succession forming the P. confluens Zone, probably of Early Asselian to Early Sakmarian age (and possibly as old as Late Carboniferous; see section 6.4) is taken as representative of deglaciation following a Late Carboniferous glacial maximum.

The sparse marine faunas of the $P$. confluens Zone in the Western Australian basins have been poorly documented in terms of stratigraphic position and assemblage composition. The exception is a surprisingly diverse fauna from the lower Calytrix Member of the Grant Formation in the Canning Basin partly documented by Foster and Waterhouse (1988) and Archbold (1995) and including foraminifera, crinoids, bryozoans, molluscs and brachiopods. The Calytrix Member is a mudstone unit with diamictite/coarse clastic units below and above it. Foster and Waterhouse (1988) concluded that the Calytrix brachiopod fauna was probably a warmer water association than assemblages known at the top of the Grant Formation. The Calytrix Member 
also contains several species of Tetrataxis, suggesting warm-water conditions, among the foraminiferal assemblage that is composed mainly of siliceous agglutinated species and Protonodosaria (Crespin, $1958 ; \mathrm{V}$. Pamieri in an unpublished 1988 report to Western Mining Corporation; Haig, unpublished studies). The precise age of the Calytrix Member is not known, although the age has been interpreted on very limited brachiopod evidence variously as Tastubian or late Asselian (Foster and Waterhouse, 1988; Archbold, 1995; Waterhouse, 2011). The Calytrix fossil assemblage seems to reflect a warm interlude that was part of a deglaciation cycle. Its time relationship to the warm spike evidenced by the latest Gzhelian bioherm in Timor cannot be determined at this stage.

In eastern Australia, Fielding et al. (2008) recognized Carboniferous-Permian glaciations from the occurrence of diamictites and drop stones. In their stratigraphic correlation chart covering many basins from the Cooper Basin in the north to the Sydney Basin in the south (Fielding et al., 2008, fig. 2) a distinct hiatus is shown, in many of the basins, spanning the Kasimovian and Gzhelian. These correlations are extremely tentative because there is no rigorous biostratigraphic control through most of the Pennsylvanian and only a few radiometric dates based on poor resolution SHRIMP zircon age control that requires reassessment with higher resolution techniques. An alternate interpretation on the timing of glaciations could be: (1) recognizing major disconformities as the times of extensive continental ice cover (and consequent lack of sediment deposition) and (2) taking the successions with diamictites and dropstones as representing episodes of deglaciation (possibly initiated by abrupt warming). The hiatus covering the Late Pennsylvanian seems to correlate with an episode of major marine regression recognized by Heckel (2008) in the cyclothem record of mid-continent North America, a sea-level fall possibly due to extensive continental glaciation. At the same time several major and well constrained highstands are now well known within the latest Gzhelian in Mid-Continent (Boardman et al., 2009; Schmitz and Davydov, 2012) (Figure 10).

The Pennsylvanian and Cisuralian stratigraphic succession in Timor is very poorly known. In this very structurally complex setting, the studied bioherm provides a narrow window into the latest Gzhelian-earliest Asselian. The stratigraphic succession below and above the bioherm has yet to be reconstructed and the sedimentation history interpreted. The bioherm indicates temperate subtropical conditions, correlates to a global warm episode, and may be coeval with the lower part of the thick glacially-influenced successions that are present in basins to the south of Timor.

\section{Conclusions}

A lensoidal limestone succession of the Maubisse Formation near the village of Kulau in the central highlands of Timor Leste is recognized as a bioherm with a massive lower unit, including reef framework at the base, and a bedded grainstone upper unit. The bioherm developed on a basalt substrate in warm shallow water, as indicated by a photozoan assemblage in the massive lower unit. Foraminifera belonging to 17 genera are recorded from the bioherm. These include representatives of biwaellids (Biwaella), schubertellids (Schubertella), schwagerinids (Schellwienia and Schwagerina) and staffellids (Parastaffella, Reitlingerina), as well as smaller less complex foraminifera. Twenty-one species have been referred to known types and 12 species are left in open nomenclature. The assemblage suggests a latest Gzhelian (and possible earliest Asselian) age.

The Kulau bioherm is significant because it is the oldest unit so far recognized in the Maubisse Formation of Timor, the oldest dated sedimentary unit known from the Outer Banda Arc, and one of the most precisely dated units in the Upper Carboniferous and Lower Permian of the East Gondwana rift system. The locality provides a significant control point, remote from better-known localities, for interpretation of global fusulinid biogeography and climate reconstruction during the latest Carboniferous and earliest Permian. At a palaeolatitude of about $40^{\circ} \mathrm{S}$ within the more-open reaches of an interior sea that flooded the East Gondwana rift system, subtropical conditions prevailed during the latest Gzhelian (and possibly earliest Asselian) coinciding with a global warm spike as suggested by fusulinid biogeography and reef development. At about the same time, a rapid influx of glacigene sediment (diamictite alternating with mudstone) took place into basins further south in the rift system, suggesting the initiation of rapid melting of continental ice sheets.

\section{Acknowledgements}

This study was partially supported by NSF grants EAR-0746042 and EAR-1004079 (VID). Funding from Eni Australia and Eni Timor Leste and the University of Western Australia supported the contributions of McCartain and Haig. We are grateful to Myra Keep for co-ordinating the UWA geological research efforts in Timor Leste, and Alfredo Pires the Secretaria de Estado dos Recursos Naturis for Timor Leste, Francisco da 

document. Changes may have been made to this work since it was submitted for publication. A definitive version was subsequently published in Palaeogeography, Palaeoclimatology, Palaeoecology, (2013). DOI: 10.1016/j.palaeo.2013.01.022

Costa Monteira and his staff at SERN, Gualdino da Silva and his staff at the Timor Leste Authoridade Nacional do Petróleo, and Noberta Soares da Costa and her staff of the Timor Leste Direcção Nacional de Geologia e Recursos Minerais for their support of our work. We particularly thank the District and Subdistrict Administrators and the Suco Chiefs for allowing us to work at the studied localities. We thank Arthur Mory and Eckart Hakansson for commenting on early drafts of the manuscript. This study would not have been possible without the field assistance of Manuel Gonçalves and Domingos Borges. 


\section{References}

Ali, J.R., Aitchison, J.C., Chik, S.Y.S., Baxter, A.T., Bryan, S.E., 2012. Paleomagnetic data support Early Permian age for the Abor Volcanics in the lower Siang Valley, NE India: Significance for Gondwanarelated break-up models. Journal of Asian Earth Sciences 50, 105-115.

Archbold, N.W., 1995. Studies on Western Australian Permian brachiopods. 12. Additions to the Late Asselian? - Tastubian faunas. Proceedings of the Royal Society of Victoria 107, 95-112.

Archbold, N.W., 2001. Pan-Gondwanan, Early Permian (Asselian - Sakmarian - Aktastinian) correlations. In: Weiss, R.H. (Ed.), Contributions to Geology and Palaeontology of Gondwana in Honour of Helmut Wopfner. Geological Institute, University of Cologne, Germany, Cologne, pp. 29-39.

Archbold, N.W., Barkham, S.T., 1989. Permian Brachiopoda from near Bisnain Village, West Timor. Alcheringa 13, 125-140.

Archbold, N.W., Bird, P.R., 1989. Permian Barchiopoda from near Kasliu Village, West Timor. Alcheringa 13, $103-123$.

Archbold, N.W., Cisterna, G.A., Simanauskas, T., 2004. The Gondwanan Carboniferous-Permian boundary revisited: New data from Australia and Argentina. Gondwana Research 7, 125-133.

Audley-Charles, M.G., 1968. The geology of Portuguese Timor. Geological Society of London, Memoir 4, 175.

Audley-Charles, M.G., 2011. Tectonic post-collision processes in Timor. Geological Society of London, Special Publication 355, 241-266

Backhouse, J., 1998. Palynological correlation of the Western Australia Permian. Proceedings of the Royal Society of Victoria 110, 107-114.

Bangert, B., Stollhofen, H., Lorenz, V., Armstrong, R.L., 1999. The geochronology and significance of ash-fall tuffs in the glacigenic, Carboniferous-Permian Dwyka Group of Namibia and South Africa. Journal of African Earth Sciences 29, 33-49.

Beauchamp, B., 1993. Carboniferous and Permian reefs of Sverdrup Basin, Canadian Arctic; an aid to Barents Sea exploration. Special Publication - Norwegian Petroleum Society, NPF 2, 217-241.

Beavington-Penney, S.J., Racey, A., 2004. Ecology of extant nummulitids and other larger benthic foraminifera: applications in palaeoenvironmental analysis. Earth-Science Reviews 67, 219-265.

Boardman, D. R., II,, Wardlaw, B. R., and Nestell, M. K., 2009. Stratigraphy and Conodont Biostratigraphy of the Uppermost Carboniferous and Lower Permian from the North American Midcontinent. Kansas Geological Survey Bulletin, Kansas Geological Survey, 255, 253 pp.

Boiko, M.S., Leonova, T.B., and Mu Lin, Phylogeny of the Permian Family Metalegoceratidae (Goniatitida, Ammonoidea), Paleontol. J., 2008,. 42, 6, 585-595.

BouDagher-Fadel, M.K., 2008. Evolution and Geological Significance of Larger Benthic Foraminifera, Developments in Palaeontology and Stratigraphy 21. Elsevier, Amsterdam, $540 \mathrm{pp}$.

Breuninger, R. H. 1976. Palaeoaplysina (hydrozoan?) carbonate buildups from upper Paleozoic of Idaho. AAPG Bulletin, 60, 584-607.

Burrows, M.T., Schoeman, D.S., Buckley, L.B., Moore, P., Poloczanska, E.S., Brander, K.M., Brown, C., Bruno, J.F., Duarte, C.M., Halperm, B.S., Holding, J., Kappel, C.V., Kiessling, W., O’Connor, M.I., Pandolfi, J.M., Parmesan, C., Schwing, F.B., Sydeman, W.J., Richardson, A.J., 2011. The pace of shifting climate in marine and terrestrial ecosystems. Science 334, 652-655.

Chamalaun, F.H., 1977a. Paleomagnetic evidence for the relative positions of Timor and Australia in the Permian. Earth and Planetary Science Letters 34, 107-112.

Chamalaun, F.H., 1977b. Palaeomagnetic reconnaissance result from the Maubisse Formation, East Timor, and its tectonic implication. Tectonophysics 42, T17-T26.

Chapman, F., Parr, W.J., 1937. On the discovery of fusulinid foraminifera in the upper Palaeozoic of north-west Australia: With a note on a new bivalve. The Victorian Naturalist 53, 175-179.

Charlton, T.R., Barber, A.J., Harris, R.A., Barkham, S.T., Bird, P.R., Archbold, N.W., Morris, N.J., Nicoll, R.S., Owen, H.G., Owens, R.M., Sourauf, J.E., Taylor, P.D., Webster, G.D., Whittaker, J.E., 2002. The Permian of Timor: stratigraphy, palaeontology and palaeogeography. Journal of Asian Earth Sciences 20, 719-774.

Chen Genbao, Yang Chenfan, Wang Xiangton, and Zhang Linxin 1991. On the boundary between Catboniferous and Permian and the Fusulinids of the boundary stratigraphy in Yunnan. Yunnan Science and Technology Publishing House, 1-74 (In Chinese), 75-106 (In English)

Chuvashov, B I., 1983. Permian reefs of the Urals. Facies, 8, 191-212.

Condon, M.A., 1967. The geology of the Carnarvon Basin, Western Australia; Part 2, Permian Stratigraphy. Australian Bureau of Mineral Resources, Geology and Geophysics, Bulletin 77, $191 \mathrm{pp}$.

Crespin, I., 1958. Permian foraminifera of Australia. Australian Bureau of Mineral Resources, Geology and Geophysics, Bulletin 48, 207 pp. 
Cummings, E.R., 1932 Reefs or Bioherms. Buletin Geological Society America 43, 331-352.

Cummings, R.H., 1962. Limestones of the Terbat formation, West Sarawak. Brit. Borneo Geol. Survey Ann. Rept., 1961, 36-48.

Davydov, V.I., 1984. On the origin of schwagerins. Paleontologischeskiy Zhurnal (4), 3-16. (In Russian)

Davydov, V.I., 1986a. Upper Carboniferous and Asselian fusulinids of the Southern Urals. In Carboniferous-Permian Boundary beds of the Urals, Pre-Urals and Central Asia. B.I. Chuvashov, E.Ya. Leven and V.I. Davydov (eds.). Nauka Publishing House, Moscow, p. 77-103. (In Russian)

Davydov, V.I., 1986b. Fusulinids of Carboniferous-Permian boundary beds of Darvas. In CarboniferousPermian Boundary beds of the Urals, Pre-Urals and Central Asia. B.I. Chuvashov, E.Ya. Leven and V.I. Davydov (eds.). Nauka Publishing House, Moscow, p. 103-125. (In Russian).

Davydov, V.I., 1992. Subdivision and correlation of Upper Carboniferous and Lower Permian deposits in Donets Basin according to fusulinid data. Soviet Geology, 5, 53-61. (In Russian.)

Davydov, V. I., 2011. Taxonomy, nomenclature, and evolution of the early schubertellid fusulinids. Acta Palaeontologica Polonica 56 (1): 181-194. doi:10.4202/app.2010.0026

Davydov, V. I., Schiappa, T.A., Snyder, S.W., 2003. Testing the Sequence Stratigraphy Model: Response of Fusulinacean Fauna to Sea Level Fluctuations (examples from Pennsylvanian and Cisuralian of PreCaspian-southern Urals Region. Micropaleontologic Proxies for Sea-Level Changes and Stratigraphic Discontinuities. SEPM Special Publication. H. C. Olson, and R. M. Leckie,. 75: 359-375.

Davydov, V.I., Glenister, B.F., Spinosa, C., Ritter, S.M., Chernykh, V.V., Wardlaw, B.R., Snyder, W.S., 1998. Proposal of Aidaralash as Global Stratotype Section and Point (GSSP) for base of the Permian System. Episodes 21, 11-17.

Davydov, V.I., Krainer, K. and Chernykh, V.V., 2013. (published on-line, Oct., 2012) Fusulinid biostratigraphy of the Lower Permian Zweikofel Formation (Rattendorf Group; Carnic Alps, Austria) and Lower Permian Tethyan chronostratigraphy. Geological Journal.

Davydov, V.I., \& Kozur, H., 1997. Position of the Carboniferous/Permian Boundary in the Carnic Alps compared with the stratotype region. Proceeding of XIII International Congress on the Carboniferous and Permian, Warszawa, 1, 123-130.

Davydov, V.I., Barskov, I.S., Bogoslovskaya, M.F., Leven, E.Ya., Popov, A.V., Akhmetshina, L.Z., \& Kozitskaya, R.I. 1992. The Carboniferous/Permian boundary in the former U.S.S.R. and its correlation. International Geology Review, 34, 90, p. 889-906.

Davydov, V.I., Nilsson, I. \& Stemmerik, L. 2001: Fusulinid zonation of the Upper Carboniferous Kap Jungersen and Foldedal Formations, southern Amdrup Land, eastern North Greenland. Bulletin Geological Society Denmark 48, 25-72.

Davydov, V.I., Schmitz, M. and Korn, Dieter. 2012. The Carboniferous Period. In: Gradstein, F., Ogg, J., Schmitz, M., and Ogg, G. (Eds.) The Geological Time Scale, 1, 603-651.

Dixon, M., Haig, D.W., 2004. Foraminifera and their habitats within a cool-water carbonate succession following glaciation, Early Permian (Sakmarian), Western Australia. Journal of Foraminiferal Research 34, 308-324.

Dunbar, C.O., Skinner, J.W., 1937. Permian Fusulinidae of Texas. University of Texas Bureau of Economic Geology and Technology Bulletin 3701, 517-825.

Ehrenberg, S. N., Pickard, N. A. H., Svana, T. A., Nilsson, I., and Davydov, V. I., 2000, Sequence stratigraphy of the inner Finnmark carbonate platform, Barents Sea: correlation between well 7128/6-1 and the shallow IKU wells, Norsk Geologisk Tidsskrift, 80, 129-162. 
Elvebakk, G., Hunt, D.W., and Stemmerik, L., 2002. From isolated buildups to buildup mosaics; 3D seismic sheds new light on upper Carboniferous-Permian fault controlled carbonate buildups, Norwegian Barents Sea. Sedimentary Geology, 152 (1-2) 7-17.

Eyles, C.H., Eyles, N., 2000. Subaqueous mass flow origin for Lower Permian diamictites and associated facies of the Grant Group, Barbwire Terrace, Canning Basin, Western Australia. Sedimentology 47, 343-356.

Eyles, C.H., Mory, A.J., Eyles, N., 2003. Carboniferous-Permian facies and tectono-stratigraphic successions of the glacially influenced and rifted Carnarvon Basin, western Australia. Sedimentary Geology 155, 6386.

Eyles, N., Mory, A.J., Backhouse, J., 2002. Carboniferous-Permian palynostratigraphy of west Australian marine rift basins: resolving tectonic and eustatic controls during Gondwanan glaciations. Palaeogeography, Palaeoclimatology, Palaeoecology 184, 305-319.

Eyles, N., Mory, A.J., Eyles, C.H., 2006. 50-million-year-long record of glacial to postglacial marine environments preserved in a Carboniferous-Lower Permian graben, Northern Perth Basin, Western Australia. Journal of Sedimentary Research 76, 618-632.

Fielding, C.R., Frank, T.D., Isbell, J.I., 2008. The late Paleozoic ice age - A review of current understanding and synthesis of global climate patterns. Geological Society of America Special Paper 441, 343-354.

Fontaine, H., 2002. Permian of Southeast Asia: an overview. Journal of Asian Earth Sciences 20, 567-588.

Fontaine, H., Vachard, D., 1984. New paleontological data on the upper Paleozoic of Sumatra. Mémoires de la Société Géologique de France, Nouvelle Serie, 147, 49-53.

Fontaine, H., Vachard, D., 1986. Appendix 1, Study of Permian samples collected from Sumatra. United National ESCAP, CCOP Technical Bulletin 18, 112-116.

Forke, H.C., Kahler, F., Krainer, K., 1998. Sedimentology, microfacies and stratigraphic distribution of foraminifers of the Lower "Pseudoschwagerina" Limestone (Rattendorf Group, Late Carboniferous), Carnic Alps (Austria/Italy). Senckenbergiana Lethaea, 78, (1-2) 1-39.

Foster, C.B., Waterhouse, J.B., 1988. The Granulatisporites confluens Oppel-zone and Early Permian marine faunas from the Grant Formation on the Barbwire Terrace, Canning Basin, Western Australia. Australian Journal of Earth Sciences 35, 135-157.

Gageonnet, R., Lemoine, M., 1958. Contribution à la Connaissance de la Géologie de la Province Portugaise de Timor. Ministério do Ultramar, Junta de Investigaçóes do Ultramar, Estudos, Ensaios e Documentos 48, $134 \mathrm{pp}$.

Glenister, B.F., Windle, D.L., Furnish, W.M., 1973. Australasian Metalegoceratidae (Lower Permian ammonoids). Journal of Paleontology 47, 1031-1043.

Gorter, J.D., Jones, P.J., Nicoll, R.S., Golding, C.J., 2005. A reappraisal of the Carboniferous stratigraphy and the petroleum potential of the southeastern Bonaparte Basin (Petrel Sub-Basin), Northwestern Australia. APPEA Journal 2005, 275-295.

Grady, A.E., Berry, R.F., 1977. Some Palaeozoic-Mesozoic stratigraphic-structural relationships in East Timor and their significance in the tectonics of Timor. Journal of the Geological Society of Australia 24, 203214.

Groves, J.R., Lee, A., 2008. Accelerated rates of foraminiferal origination and extinction during the late Paleozoic ice age. Journal of Foraminiferal Research 38, 74-84.

Gulbranson, E.L., Montañez, I.P., Schmitz, M.D., Limarino, C.O., Isbell, J.L., Marenssi, S.A., Crowley, J.L., 2010. High-precision U-Pb calibration of Carboniferous glaciation and climate history, Paganzo Group, NW Argentina. Geological Society of America Bulletin 122, 1480-1498.

Haig, D.W., 2003. Palaeobathymetric zonation of foraminifera from lower Permian shale deposits of a highlatitude southern interior sea. Marine Micropaleontology 49, 317-334.

Haig, D.W., 2004. Comparison of foraminifera and habitats from Australian Permian and Cretaceous interior seas. Memoirs of the Association of Australasian Palaeontologists 29, 31-46.

Haig, D. W., 2012. Palaeobathymetric gradients across Timor during 5.7-3.3 Ma (latest Miocene - Pliocene) and implications for collision uplift. Palaeogeography, Palaeoclimatology, Palaeoecology 331-332, 50-59.

Hall, R., 2011. Australia-SE Asia collision: plate tectonics and crustal flow. Geological Society, London, Special Publications 355, 75-109.

Harrowfield, M., Holdgate, G.R., Wilson, C.J.L., McLoughlin, S., 2005. Tectonic significance of the Lambert graben, East Antarctica: Reconstructing the Gondwanan rift. Geology 33, 197-200.

Heckel, P.H., 2008. Pennsylvanian cyclothems in Midcontinent North America as far-field effects of waxing and waning of Gondwana ice sheets. Geological Society of America Special Paper 441, 275-289.

Heine, C., Müller, R.D., 2005. Late Jurassic rifting along the Australian North West Shelf: marine geometry and spreading ridge configuration. Australian Journal of Earth Sciences 52, 27-39.

Hocking, R.M., Moors, H.T., Van de Graaff, W.J.E., 1987. Geology of the Carnarvon Basin, Westeern Australia. Geological Survey of Western Australia Bulletin 133, 289 pp. 
NOTICE: this is the author's version of a work that was accepted for publication in Palaeogeography, Palaeoclimatology, Palaeoecology. Changes resulting from the publishing process, such as peer review, editing, corrections, structural formatting, and other quality control mechanisms may not be reflected in this document. Changes may have been made to this work since it was submitted for publication. A definitive version was subsequently published in Palaeogeography, Palaeoclimatology, Palaeoecology, (2013). DOI: 10.1016/j.palaeo.2013.01.022

Hohenegger, J., 2004. Depth coenoclines and environmental considerations of western Pacific larger Foraminifera. Journal of Foraminiferal Research 34, 9-33.

Hutchison Ch. S. 2005. Geology of north-west Borneo : Sarawak, Brunei and Sabah. Elsevier.

Isbell, J.L., Miller, M.F., Wolfe, K.L., Lenaker, P.A., 2003. Timing of late Paleozoic glaciation in Gondwana: Was glaciation responsible for the development of northern hemisphere cyclothems? Geological Society of America Special Paper 370, 5-24.

James, J.L., 1997. The cool-water carbonate depositional realm. In: James, N. P. and Clarke, J.A.D. (Eds.), 1997. Cool-water carbonates. Society of Economic Paleontologists and Mineralogists, Special Publication 56, 1-20.

James, N.P., \& Wood, R.A., 2010. Reefs. In: James, N.P., and Dalrymple, R.W. (eds.) Facies Models 4. Geological Association of Canada GeoText 4, 421-447.

Jin, Y. G., Glenister, B. F., Furnish, W. M., Kotlyar, G. v., Wardlaw, B. R., Kozur, H., Ross, C., Spinosa, C., 1994. Revised operational scheme of Permian chronostratigraphy. Permophiles, 15, 15-25.

Kalvoda, J., 2002. Late Devonian-Early Carboniferous Foraminiferal Fauna: Zonations, Evolutionary events, paleobiogeography and tectonic implications. Folia, Geologia, 39, Masaryk University, Brno, Czech Republic.

Keep, M., Haig, D.W., 2010. Deformation and exhumation in Timor: Distinct stages of a young orogeny. Tectonophysics 483, 93-111.

Khodjanyazova, R., and Mamet, B., 2003. Paleozoic calcareous algae from southern Tien Shan, Uzbekistan, Central Asia. Geologica Belgica, 6, (3-4), 97-117.

Kireeva, G.D., Shcherbovich, S.F., Dobrokhotova, S.V., Ketat, O.B., Mal'kovskiy, F.S., Semina, S.A., Chernova, I.A., Yagofarova, F.Z., 1971. Zona Schwagerina vulgaris - Schwagerina fusiformis Assel'skogo yarusa Russkoy Platformy i zapadnogo sklona yuzhnogo Urala. Voprosy Mickropaleontologii 14, 70-102.

Kobayashi, F., and Ishii, Ken-Ichi, 2003. Permian fusulinaceans of the Surmaq Formation in the Abadeh region, central Iran. Rivista Italiana di Paleontologia e Stratigrafia, 109 (2) 307-337.

Konovalova, M.V., 1991. Stratigraphia i fuzulinidi verkhnego karbona in nizhnei permi Timano-Pechorskoi heftegazonosnoi provintsii. Ukhta Geological-Exploration Expedition. Nedra Publishing House, Moscow (In Russian)

Korte, C., Jones, P.J., Brand, U., Mertmann, D., Veizer, J., 2008. Oxygen isotope values from high-latitudes: Clues for Permian sea-surface temperature gradients and Late Palaeozoic deglaciation. Palaeogeography, Palaeoclimatology, Palaeoecology 269, 1-16.

Krainer, K., 1995. Anthracoporella mounds in the Late Carboniferous Auernig Group, Carnic Alps (Austria). Facies, 33, 195-214.

Leonova, T. B., 2011. "Permian Ammonoids : Biostratigraphic, Biogeographical, and Ecological Analysis." Paleontological Journal, 2011, Vol. 45, No. 10, pp. 1206-1312.

Leven, E. Ya., 1997. Special Permian stratigraphy and Fusulinida of Afghanistan with their paleogeographic and paleotectonic implications. Geological Society of America Special Papers, 316.

Leven, E.Ya., and Gorgij, M.N. 2006. First discovery of Gzhelian fusulinids in central Iran. Stratigrafiya, Geologicheskaya Korrelyatsiya, 14 (1), 22-32.

Leven, E.Ya., and Gorgij, M.N. 2011. First occurrence of Gzhelian and Asselian fusulinids in Vajnan Formation; Sanandaj-Sirjan Zone, Iran. Stratigrafiya Geologicheskaya Korrelyatsiya, 19 (5) 16-31.

Leven, E.Ya., and Scherbovich, S.F., 1978. Fusulinidi i Assel'skaya stratigraiya Darvaza., Bulleten' Moscovskogo Obshchestva Ispitatelei Prirody, seriya geologicheskaya. Nauka Publishing House, Moscow (In Russian).

Leven, E. J. and A. Taheri (2003). "Carboniferous-Permian stratigraphy and fusulinids of east Iran; Gzhelian and Asselian deposits of the Ozbak-Kuh region." Rivista Italiana di Paleontologia e Stratigrafia 109(3): 399-415.

Li, Z.X., Powell, C. McA., 2001. An outline of the palaeogeographic evolution of the Australasian region since the beginning of the Neoproterozoic. Earth-Science Reviews 53, 237-277.

Lonoy, A.,1988. Environmental setting and diagenesis of Lower Permian palaeoaplysinid build-ups and associated sediments from Bjornoya; implications for the exploration of the Barents Sea. Journal of Petroleum Geology, 11 (2), 141-156.

Lukin, A. Ye., and Galitskiy, I. V. 1974. Bioherms in the Lower Permian of the Dnieper-Donets Basin. Doklady. Earth Science Sections, 215 (1-6), 24-26 (In Russian).

Mamet, B.L. 1974. Taxonomic note on Carboniferous Endothyracea. Journal of Foraminiferal Research 4, 200204.

Mantle, D.J., Kelman, A.P., Nicoll, R.S., Laurie, J.R., 2010. Australian Biozonation Chart 2010. Geoscience Australia, Canberra. 
Maslo, A., Vachard, D., 1997. Inventaire critique des Eostaffellinae (Foraminifères) du Carbonifère. Revue de Micropaléontologie 40, 39-69.

Metcalfe, I., 2006. Palaeozoic and Mesozoic tectonic evolution and palaeogeography of East Asian crustal fragments: The Korean Peninsula in context. Gondwana Research 9, 24-46.

Mayhew,P.J., Bell, M.A., Benton, T.G. and McGowan, A.J. 2012. Biodiversity tracks temperature over time. PNAS, published on-line, September 4, 2012, p.1-5.

Mory, A.J., Backhouse, J., 1997. Permian stratigraphy and palynology of the Carnarvon Basin, Western Australia. Geological Survey of Western Australia Report 51, 41 pp.

Mory, A.J., Beere, G.M., 1988. Geology of the onshore Bonaparte and Ord Basins in Western Australia. Geological Survey of Western Australia Bulletin 134, 179 pp.

Mory, A.J., Redfern, J., Martin, J.R., 2008. A review of Permian-Carboniferous glacial deposits in Western Australia. Geological Society of America Special Paper 441, 29-40.

Murray, J., 2006. Ecology and Applications of Benthic Foraminifera. Cambridge University Press, Cambridge, 50, 426pp.

Needham, C. E. 1937. Some New Mexico Fusulinidae, New Mexico School Mines Bull. 14. pp. 88.

Nilsson, I., and Davydov, V.I. 1997. Fusulinid biostratigraphy in Upper Carboniferous (Gzhelian) and Lower Permian (Asselian-Sakmarian) succession in Spitsbergen, Arctic Norway Permophiles, no 30, p.18-27.

Nogami, Y., 1963. Fusulinids from Portuguese Timor (Palaeontological Study of Portuguese Timor, 1). Memoirs of the College of Science, Univeristy of Kyoto, Series B, 30, 59-69.

Playford, P.E., Cockbain, A.E., Low, G.H., 1976. Geology of the Perth Basin Western Australia. Geological Survey of Western Australia Bulletin 124, 311 pp.

Rauser-Chernousova, D.M., \& Fursenko, A.V. 1937. Spravochmik foraminifer heftenosnykh raionov SSSR. Part 1. Moscow, pp. 3-320 (In Russian)

Rauser-Chernousova, D.M., Gryzlova, N.D., Kireeva, G.D., Leontovich, G.E., Safonova, T.P., Chernova, E.I., 1951. Srednekamennougol'nye Fuzulinidy Russkoy Platformy I soprefel'nykh oblastey. Akademiya Nauk SSSR, Institut Geologicheskiy Nauk, Moscow.

Rauser-Chernousova, D.M., and Scherbovich, S.F.. 1958. Schwagerinovyi Gorizont Tsentral'noi chasti Russkoi Platformi, in V.V. Menner (Ed.) Schwagerinovyi Gorizont in podstilayushchie otlozheniya Russkoi Platformi. Transactions of Geological Institute of Academy of Sciences of USSR, 13, 3-56, (In Russian).

Reeckmann, S.A., Mebberson, A.J., 1984. Igneous intrusions in the North-West Canning Basin and their impact in oil exploration. In: Purcell, P.G. (Ed.), The Canning Basin, W.A.: Proceedings of Geological Society of Australia, Petroleum Exploration Society of Australia Symposium, Perth 1984; pp. 389-399.

Remizova, S.T. 1995. Foraminifer i biostratigraphiay verknego karbona Severnogo Timana. Transactions of KOMI Scientific Centre of Uralian branch of Russian Academy of Sciences, Syktyvkar (In Russian).

Ross, C.A., 1982. Paleobiology of fusulinaceans. Proceedings of the North American Paleontological Convention 3, 441-445.

Ross, C. A., 1995. Permian fusulinaceans. In: Scholle, P.A., Peryt, T.M., Ulmer-Scholle, D.S. (Eds.). The

Permian of Pangea; Volume I, Paleogeography, paleoclimates, stratigraphy, Springer-Verlag, Berlin,

Federal Republic of Germany, pp. 167-185.

Ross, C.A., Ross, J.R.P., 1995. Foraminiferal zonation of Late Paleozoic depositional sequences. Marine Micropaleontology 26, 469-478.

Ruzhencev, V.E., Biostratigrafiya sakmarskogo yarusa v Aktyubinskoi oblasti Kazakhskoi SSR, Trudy Paleontologicheskogo Instituta Academii Nauk SSSR. (Biostratigraphy of the Sakmarian Stage in the Aktyubinsk Region of the Kazakh SSR: Proc. Paleontol. Inst. Acad. Sci. USSR, 42, Moscow, 89 pp.

Samuelsberg, T. J., Elvebakk, G., and Stemmerik, L., 2003. Late Palaeozoic evolution of the Finnmark Platform, southern Norwegian Barents Sea. Norsk Geologisk Tidsskrift, 83. (4), 351-362.

Sanderson, G.A., 1966 Presence of Carboniferous in West Sarawak. Bulletin of the American Association of Petroleum Geologists, vol.50, issue, part 1, p. 578-580.

Schmitz, M.D., Davydov, V.I., 2012. Quantitative radiometric and biostatigraphic calibration of the Pennsylvanian-Early Permian (Cisuralian) time scale and pan-Euramerican chronostratigraphic correlation. Geological Society of America, Bulletin 124, 549-577.

Schubert, R., 1915. Die Foraminiferen des jüngeren Paläozoikums von Timor. Paläontologie von Timor 2, 4959.

Sjomina, S.A. 1961. Stratigraphiya i foraminiferi (fuzulinidi) of Schwagerinovogo Gorizonta Oksko-Tsninskogo Vala. Transactions of Geological Institute of Academy of Science of the U.S.S.R., 57, pp.1-72 (In Russian).

Skaug, M., Dons, C. E., Lauritzen, O., and Worsley, D., 1982. Lower Permian palaeoaplysinid bioherms and associated sediments from central Spitsbergen. Polar Research 2, 57-75. 
Skwarko, S.K., (Ed.), 1993. Palaeontology of the Permian of Western Australia. Geological Survey of Western Australia Bulletin 136, 417 pp.

Stanley, S.M., 1984. Temperature and biotic crises in the marine realm. Geology 12, 205-208.

Stemmerik, L., Larson, P. A., Larssen, G. B., Mork, A., and Simonsen, B. T. 1994. Depositional evolution of Lower Permian Palaeoaplysina build-ups, Kapp Duner Formation, Bjornoya, Arctic Norway. Sedimentary Geology92. 3-4(September 1994): 161-174.

Stephenson, M.H., 2009. The age of the Carboniferous-Permian Converrucosisporites confluens Oppel Biozone: new data from the Ganigobis Shale Member (Dwyka Group) of Namibia. Palynology 33, 167-177.

Stollhofen, H., Stanistreet, I.G., Bangert, B., Grill, H., 2000. Tuffs, tectonism and glaciallyrelated sea-level changes, Carboniferous-Permian, southern Namibia. Palaeogeography, Palaeoclimatology, Palaeoecology 161, 127-150.

Thompson, M.L., 1936. Lower Permian fusulinids from Sumatra. Journal of Paleontology 10, 587-592.

Thompson, M.L., 1949. The Permian fusulinids of Timor. Journal of Paleontology 23, 182-192.

Ueno, K., Wang, Y., and Wang, X., 2003. Fusulinoidean faunal succession of a Paleo-Tethyan oceanic seamount in the Changing-Menglian Belt, west Yunnan, southwest China; an overview. Island Arc, 12 (2), 145-161.

Vachard, D., 1990. A new biozonation of the limestones from Terbat area, Sarawak, Malaysia, in: Fontaine H (Ed.), Ten years of CCOP Research on the Pre-Tertiary of East Asia. CCOP Techn. Publ. 20, 183-208.

Vachard, D., Munnecke, A., and Servais, Th., 2004. New SEM observations of keriothecal walls; implications for the evolution of Fusulinida. Journal of Foraminiferal Research, 34 (3), 232-242.

Vergel, M., 2008. Palynology of late Palaeozoic sediments (Tupe Formation) at La Herradura Creek, San Juan province, Argentina. Alcheringa: An Australian Journal of Palaeontology, 32, 339-352,

Vilesov, A.P., 2000. Fusulinid-based Zonation of the Melekhovian Horizon (Upper Carboniferous, Gzhelian Stage) in the Perm' Region. Stratigraphy and Geological Correlation, 8 (5), 447-460.

Volozhanina, P.P., 1962. Fuzulinidi verkhnego karbona Timano-Pechori. Voprosi Micropaleontologii, 6, 116146 (In Russian).

Wahlman, G.P., 2002. Upper Carboniferous-Lower Permian (Bashkirian-Kungurian) mounds and reefs. Special Publication, Society for Sedimentary Geology, 72, 271-338.

Waterhouse, B., 2011. Origin and evolution of Permian brachiopods of Australia. Memoirs of the Association of Australasian Palaeontologists 41, 205-228.

Watkins, R., and Wilson, E. C., 1989.Paleoecologic and biogeographic significance of the biostromal organism Palaeoaplysina in the Lower Permian McCloud Limestone, eastern Klamath Mountains, California. Palaios, 4 (2), 181-192.

Winguth, A.M.E., Heinze, C., Kutzbach, J.E., Maier-Reimer, E., Mikolajewicz, U., Rowley, D., Rees, A., Ziegler, A.M., 2002. Simulated warm polar currents during the Middle Permian. Paleoceanography 17, $1-19$.

Wopfner, H., 1999. The Early Permian deglaciation event between East Africa and northwestern Australia. Journal of African Earth Sciences 29, 77-90.

Wopfner, H., Jin, X.C., 2009. Pangea Megasequences of Tethyan Gondwana-margin reflect global changes of climate and tectonism in Late Palaeozoic and Early Triassic times — A review. Palaeoworld 18, 169192.

Xiao, W., Wang, H., Zhang, L., and Dong, W., 1986. Early Permian Stratigraphy and faunas in Southern Guizhou. People's Publishing House of Guizhou, pp. 1-364.

Ziegler, A.M., Hulver, M.L., Rowley, D.B., 1997. Permian world topography and climate. In: Martini, I.P. (Ed.), Late Glacial and Post-Glacial Environmental Changes-Quaternary, Carboniferous-Permian and Proterozoic. Oxford University Press, New York; pp. 11-146. 


\section{Explanation of figures}

Figure 1. Position of Timor within the East Gondwana rift system after the Early Permian rifting (Metcalfe, 2006) of the SIBAMASU / Cimmerian continental terrane along the Meso / Neo Tethyan ocean boundary (modified from Harrowfield et al., 2005). Within the interior-rift system, dash lines indicate positions of rifts during final continental breakup (at $155 \mathrm{Ma}$ in the vicinity of Timor; $136 \mathrm{Ma}$ off southwest Australia; Heine and Müller, 2005). Palaeolatitudes follow Li and Powell (2001).

Figure 2. STRM image of Timor (compiled from NASA US Shuttle Radar Topography Mission images) showing the location of the Kulau study site. The insert map shows Timor as part of the non-volcanic Outer Banda Arc.

Figure 3. Map of Timor showing extent of Gondwana Megasequence (including the Maubisse Formation) and the outcrop at Kulau. Insert image A is an aerial photograph of the Kulau area; image B is an enlarged view showing the extent of the studied bioherm.

Figure 4. Stratigraphic log of the studied bioherm showing position of collected samples listed in Tables 1-3 and referenced in the text.

Figure 5. Massive limestone unit (MLU) comprising the basal massive photozoan sub-unit (MPSU) and overlying massive heterozoan sub-unit (MHSU). A) contact between vesicular basalt (v) and overlying massive limestone (1) of MPSU with a 'reef' framework, locality 6. B) framework of aborescent algae? (a) and colonial rugose corals from the MPSU, locality 6. C) large gastropods (g) and coral fragments (c) with a framework of arborescent algae (?) from the MPSU, locality 6. D) branching corallum (c) with large diameter corallites from the MPSU locality 6. E) cliff section of massive limestone unit (MLU) overlain by the bedded grainstone unit (BGU) at locality 4, dashed line indicates contact of MLU with the underlying vesicular basalt. F) massive limestone unit showing contact between bedded grainstone unit (BGU) and the MLU, the latter displays karstic weathering, locality 2. G. base of MLU showing "lens" of limestone (1) within basalt below the main contact with MLU where person is sitting, locality 6.

Figure 6. Bedded grainstone unit (BGU). A) BGU in river, locality 6. B) Enlarged view of outcrop showing bedding pattern comprising more friable laminae to thin beds of mudstone alternating with limestone beds, locality 6. C) Cliff face outcrop showing lower beds of BGU with evidence for lateral variation in limestone bed thicknesses (e.g. black arrow) and symmetrical wave ripple crests (see inset showing area within black box) defined by laminae of mudstone, locality 5. D) BGU showing a limestone dominated interval with thin beds to laminae of friable red mudstone, locality 2. E) Laminae of mudstone within limestone beds of the BGU often define flaser (f), wavy (w) or planar cross-laminated (p) sedimentary structures, locality 2.

Figure 7. Late Gzhelian-early Asselian paleogeography (from Blakey, http://jan.ucc.nau.edu/rcb7/mollglobe.html with slight modifications) showing distribution of buildups; highly diverse tropical fusulinid and less diverse temperate (Schellwienia-Schwagerina dominated) faunas. 1, Texas, New-Mexico and Arizona; 2, North America Great Basin; 3, McCloud; 4, Yukon, Alaska; 5, Canadian Arctic; 6, Spitsbergen and Barents Sea; 7, Timan-Pechora; 8, Russian Platfortm and Southern_Urals; 9, Donets Basin; 10, Pre-Caspian; 11, Central_Asia; 12, Carnic_Alps; 13, North_China; 14, South_China; 15, Central Iran, Sanandaj-Sirjan Zone; 16, Yunnan (Sibumasu); 17, Timor

Figure 8. Correlation chart comparing known faunas in Timor, Sarawak, Sumatra and Western Yunnan with the fusulinid zones and regional stages in the Urals.

Figure 9. Correlation chart comparing the Timor succession with units known further south in the East Gondwana rift system. In Timor, the stratigraphy above the Gzhelian is schematic with precise positions of bioherms, bedded limestone and reworked volcanic units uncertain. In the Bonaparte, Canning, Southern Carnarvon, and Northern Perth Basins, the ages of the lower parts of the Kulshill Group, Grant Group, Lyons Group, and Nangetty Formation are uncertain but may range down into the Gzhelian (see discussion in Section $6.4)$

Figure 10. Correlation charts of marine beds within the Carboniferous-Permian transition of Cimmerian blocks, Central Asia, Urals and North American Midcontinent with the data on fusulinid biodiversity from Northern Pangaea (Davydov et al., 2012). Note, the highest peak in diversity coincides with the global warming spike documented in Timor and elsewhere and lower diversity correspond with glacial events. 


\section{Explanation of Tables}

Table 1: Locality co-ordinates and description.

Table 2. Grain constituents in studied samples from the Kulau bioherm.

Table 3: Distribution of foraminifera and algae in the studied samples

\section{Appendix 1: \\ New observations on the Biangping section, Southern China, relevant to age determination of the Timor fauna}

The restudy of the Carboniferous-Permian transition in the Biangping section (Xiao et al., 1986; Davydov, 1995) reveals the internationally accepted Carboniferous-Permian boundary (at the base of the Sphaeroschwagerina vulgaris and Sch. fusiformis fusulinid zone) within the "Pseudoschwagerina uddeni" zone. Fusulinid assemblages in the boundary deposits in the Biangping section show considerable endemism, hampering correlation. Nevertheless some fusulinid species widespread in the stratotype area in the Southern Urals were found at Biangping (Davydov, 1995), and this section also contains species present in Timor. Because of its significance in correlating the Timor beds, a discussion of the Biangping section is presented below.

Bed 7 in the Biangping section can be correlated with the lower part of the Gzhelian due to the presence of Rauserites variabilis Rosovskaya, $R$. shikhanensis Rosovskaya, and rather primitive Rugosofusulina. Equivalents of the middle Gzhelian fusulinid Jigulites jigulensis zone lying between beds 7 and 13 were not sampled by Davydov (1995). All the other sampled beds in the Biangping section correlate with the Aidaralash section that includes the GSSP of the Carboniferous-Permian boundary at the base of bed 19-5f (Davydov et al., 1998).

The taxonomy of fusulinids from bed 13 at Biangping is difficult with local species dominating. The occurrence of Schellwienia malkovskyi and Schwagerina subrobusta, however, enables correlation of bed 13 of the Biangping section with beds 10-13 of the Aidaralash section. Based on the occurrence of Schwagerina gracilis and Schw. vozhgalensis, bed 14 of the Biangping section can be approximately correlated with beds 14 15 of the Aidaralash section (Davydov et al.,1992). Bed 16-0 is precisely correlated with beds 16-17 of the Aidaralash section. This is supported by the occurrence of Ultradaixina cheni similar to Ultradaixina bosbytauensis, occurring in beds 15-16 of the Aidaralash section (Davydov et al., 1992). Schwagerina bianpingensis, common in the documented Timor assemblage, also has been found in this bed. At this level in the Aidaralash and Biangping sections the first Rugosochusenella occurs. In the Donets Basin and Carnic Alps, the first occurrence of Boultonia cheni is recorded in the Ultradaixina bosbytauensis-Schwagerina robusta zone (Davydov, 1992; Davydov and Kozur, 1997). Ultradaixina, apparently represented by a new species, has been found together with Likharevites paranitidus auritus in bed 16-4 at Aidaralash section, S. Urals. The latter subspecies in South Fergana, Uzbekistan characterizes beds directly underlying the Asselian (Popov et al., 1989). Likharevites paranitidus paranitidus is known in beds 18-19 in the Aidaralash section (Davydov et al., 1992). The acme of Likharevites in the Aidaralash section falls in upper Gzhelian beds 18-19/5 (Davydov et al., 1998). The index for the base of the Asselian, the first appearance of the Sphaeroschwagerina vulgaris group, occurs in bed 16-8 in the Biangping section. Species such as S. kolvica, S. ex gr. fusuformis, and S. ex gr. sphaerica are most similar to the corresponding fusulinids from beds 20-21 in the Aidaralash section, i.e. from the very base of the lower Asselian Sphaeroschwagerina vulgaris aktjybensis-S.fusuformis zone (Davydov, 1986a). The distributions stated above suggest that the C/P boundary in the Biangping section should be placed between beds 16-4 and 16-8 (Davydov, 1995).

Additional evaluation of the fusulinids from the Biangping section was made during the present study and several species common to Timor and Biangping were found. In particular, Schellwienia klunnikovi, has been found in beds 13 through 16-8 in Biangping; Schellwienia malkovskyi is present in bed 13; Schwagerina gracilis occurs in beds 13 through 16-0; Schwagerina subrobusta is in bed 14; Schwagerina bianpingensis is present in bed 16-0; and Schwagerina vozhgalensis) ranges from bed 14 through bed 16-4. Thus, these species from the Timor bioherm suggest a correlation to the uppermost Gzhelian in the Biangping section.

\section{References not cited in "References"}

Davydov, V.I., 1995, The Carboniferous/Permian boundary in South China: Permophiles, no. 26, p. 9-11. Popov A.V., Davydov, V.I., and Kossovaya O.L.1989,On stratigraphy of Gzhelian of Central Asia. Sovetskaya Geologiya (Sov.Geol.), 3:64-76. (in Russian). 
NOTICE: this is the author's version of a work that was accepted for publication in Palaeogeography, Palaeoclimatology, Palaeoecology. Changes resulting from the publishing process, such as peer review, editing, corrections, structural formatting, and other quality control mechanisms may not be reflected in this document. Changes may have been made to this work since it was submitted for publication. A definitive version was subsequently published in Palaeogeography, Palaeoclimatology, Palaeoecology, (2013). DOI: 10.1016/j.palaeo.2013.01.022

\begin{tabular}{|c|c|c|c|c|c|}
\hline $\begin{array}{l}\text { UWA } \\
\text { Number }\end{array}$ & $\begin{array}{l}\text { Field } \\
\text { Number }\end{array}$ & $\begin{array}{l}\text { Locality } \\
\text { (Fig. 3) }\end{array}$ & $\begin{array}{l}\text { Latitude } \\
\left({ }^{\circ} \mathbf{S}\right)\end{array}$ & $\begin{array}{l}\text { Longitude } \\
\left({ }^{\circ} \mathbf{E}\right)\end{array}$ & Description \\
\hline \multirow[t]{2}{*}{144295} & S6129 & 2 & 8.81604 & 125.54704 & In massive limestone with karstic weathering \\
\hline & S5119 & & & & \\
\hline 158342 & $4 / 11 / 11-1$ & 2 & 8.81591 & 125.54733 & $\begin{array}{l}\text { Section in bedded limestone on south side of road; } 0.5 \mathrm{~m} \text { above base of } \\
\text { bedded section (base of bedded section indicated by co-ordinates) }\end{array}$ \\
\hline 158343 & $4 / 11 / 11-2$ & 2 & 8.81591 & 125.54733 & $\begin{array}{l}\text { Section in bedded limestone on south side of road; } 1.2 \mathrm{~m} \text { above base of } \\
\text { bedded section (base of bedded section indicated by co-ordinates) }\end{array}$ \\
\hline 158344 & $4 / 11 / 11-3$ & 2 & 8.81591 & 125.54733 & $\begin{array}{l}\text { Section in bedded limestone on south side of road; } 2 \mathrm{~m} \text { above base of } \\
\text { bedded section (base of bedded section indicated by co-ordinates) }\end{array}$ \\
\hline 158345 & $4 / 11 / 11-4$ & 2 & 8.81591 & 125.54733 & $\begin{array}{l}\text { Section in bedded limestone on south side of road; } 2.8 \mathrm{~m} \text { above base of } \\
\text { bedded section (base of bedded section indicated by co-ordinates) }\end{array}$ \\
\hline 158346 & $4 / 11 / 11-5$ & 2 & 8.81591 & 125.54733 & $\begin{array}{l}\text { Section in bedded limestone on south side of road; } 3.9 \mathrm{~m} \text { above base of } \\
\text { bedded section (base of bedded section indicated by co-ordinates) }\end{array}$ \\
\hline 158347 & $4 / 11 / 11-6$ & 2 & 8.81591 & 125.54733 & $\begin{array}{l}\text { Section in bedded limestone on south side of road; } 4.6 \mathrm{~m} \text { above base of } \\
\text { bedded section (base of bedded section indicated by co-ordinates) }\end{array}$ \\
\hline 158348 & $4 / 11 / 11-7$ & 2 & 8.81591 & 125.54733 & $\begin{array}{l}\text { Section in bedded limestone on south side of road; } 5.7 \mathrm{~m} \text { above base of } \\
\text { bedded section (base of bedded section indicated by co-ordinates) }\end{array}$ \\
\hline 158349 & $4 / 11 / 11-8$ & 2 & 8.81591 & 125.54733 & $\begin{array}{l}\text { Section in bedded limestone on south side of road; } 7.3 \mathrm{~m} \text { above base of } \\
\text { bedded section (base of bedded section indicated by co-ordinates) }\end{array}$ \\
\hline 158350 & $4 / 11 / 11-9$ & 2 & 8.81591 & 125.54733 & $\begin{array}{l}\text { Section in bedded limestone on south side of road; } 8.4 \mathrm{~m} \text { above base of } \\
\text { bedded section (base of bedded section indicated by co-ordinates) }\end{array}$ \\
\hline 158351 & $4 / 11 / 11-10$ & 2 & 8.81591 & 125.54733 & $\begin{array}{l}\text { Section in bedded limestone on south side of road; } 9.4 \mathrm{~m} \text { above base of } \\
\text { bedded section (base of bedded section indicated by co-ordinates) }\end{array}$ \\
\hline 158353 & $5 / 11 / 11-2$ & 2 & 8.81627 & 125.54707 & $\begin{array}{l}\text { In massive limestone with karstic weathering below the bedded section } \\
\text { samples in samples } 4 / 11 / 11-1 \text { to } 10\end{array}$ \\
\hline 158355 & $5 / 11 / 11-4$ & 2 & 8.81604 & 125.54704 & In massive limestone with karstic weathering \\
\hline 158356 & $5 / 11 / 11-5$ & 2 & 8.81607 & 125.54698 & In massive limestone with karstic weathering \\
\hline 158357 & $5 / 11 / 11-6$ & 2 & 8.81597 & 125.54719 & In massive limestone with karstic weathering \\
\hline 158366 & $5 / 11 / 11-15$ & 6 & 8.81375 & 125.54888 & $\begin{array}{l}\text { In River Maun Lari; in lowest part of a massive limestone bioherm (about } 5 \\
m \text { thick) lying on vesicular basalt }\end{array}$ \\
\hline 158367 & $5 / 11 / 11-16$ & 6 & 8.81375 & 125.54888 & $\begin{array}{l}\text { In River Maun Lari; in limestone interbed in vesicular basalt about } 2 \mathrm{~m} \\
\text { below bioherm sampled in } 5 / 11 / 11-15\end{array}$ \\
\hline
\end{tabular}


NOTICE: this is the author's version of a work that was accepted for publication in Palaeogeography, Palaeoclimatology, Palaeoecology. Changes resulting from the publishing process, such as peer review, editing, corrections, structural formatting, and other quality control mechanisms may not be reflected in this document.

Changes may have been made to this work since it was submitted for publication. A definitive version was subsequently published in Palaeogeography

Palaeoclimatology, Palaeoecology, (2013). DOI: 10.1016/j.palaeo.2013.01.022

rock type (rst: rudstone. gst:

average grain size (visual

estimate; grn: granule. vcs: very

coarse sand)

sorting (visual estimate; mod:

moderate)

dolomitization (mod: moderate)

silicification

$\%$ of total bioclasts

foraminifera

tubiphytes

crinoid plates

brachiopod fragments

bryozoans

dasycladacean algae

cyanobacteria (? Girvanella)

ostracods

gastropods

rugose coral

echinoid spines
MASSIVE BIOHERM

\begin{tabular}{c|c}
\multicolumn{2}{c}{ MASSIVE BIOHERM } \\
\hline MPSU & MHSU
\end{tabular}

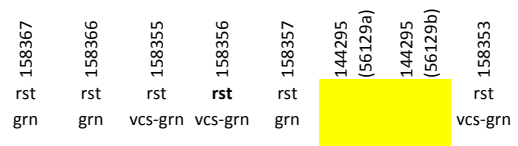

poor poor poor poor poor

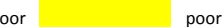

poor$$
29
$$

$\begin{array}{cc}62 & 43 \\ 29(?) & 48 \\ 9 & 3 \\ 5 & <1 \\ & 3\end{array}$

$15 \quad 30$

$3<10<1$

$\begin{array}{lll}1 & <1 & 3 \\ 1 & & \end{array}$

$1<1<1$

$<1$

$\begin{array}{lll}<1 & 1 & <1 \\ & & <1\end{array}$
MEDIUM TO THICK BEDDED GRAINSTONE

\begin{tabular}{|c|c|c|c|c|c|c|c|c|c|}
\hline \multicolumn{10}{|c|}{ BGU } \\
\hline 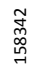 & $\begin{array}{l}\stackrel{m}{\tilde{N}} \\
\stackrel{\infty}{\sim} \\
\stackrel{\neg}{ }\end{array}$ & $\begin{array}{l}\stackrel{J}{\leftrightarrows} \\
\stackrel{\infty}{\infty} \\
\stackrel{\sim}{\sim}\end{array}$ & 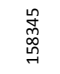 & $\begin{array}{l}\stackrel{0}{1} \\
\stackrel{N}{0} \\
\stackrel{0}{\sim}\end{array}$ & $\begin{array}{l}\hat{f} \\
\stackrel{\infty}{\infty} \\
\stackrel{\infty}{\sim}\end{array}$ & 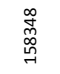 & $\begin{array}{l}\stackrel{g}{+} \\
\stackrel{\infty}{\infty} \\
\stackrel{\sim}{\sim}\end{array}$ & $\begin{array}{l}\text { 怘 } \\
\text { 心 } \\
\stackrel{心}{\rightarrow}\end{array}$ & $\begin{array}{l}\text { 개 } \\
\tilde{\infty} \\
\stackrel{\sim}{\sim}\end{array}$ \\
\hline gst & gst & gst & gst & gst & gst & gst & gst & gst & gst \\
\hline vcs & vcs & vcs & vcs & & vcs & & vcs & vcs & vcs \\
\hline $\begin{array}{c}\text { mo } \\
\mathrm{d}\end{array}$ & $\bmod$ & mod & & & $\bmod$ & $\bmod$ & mod & mod & mod \\
\hline $\mathrm{ma}$ & $\bmod$ & minor & $>80 \%$ & $\sim 100 \%$ & major & minor & minor & & $\begin{array}{l}\text { minor } \\
\text { minor }\end{array}$ \\
\hline$<1$ & $<1$ & $<1$ & vr & & $<1$ & $<1$ & $<1$ & & $<1$ \\
\hline 29 & 14 & 51 & C & & 38 & 25 & 24 & 43 & 22 \\
\hline 1 & & 2 & & & 1 & $<1$ & $<1$ & $<1$ & $<1$ \\
\hline 70 & 86 & 47 & A & & 61 & 75 & 76 & 56 & 78 \\
\hline
\end{tabular}

$<1<1 \quad<1$ 

publication. A definitive version was subsequently published in Palaeogeography, Palaeoclimatology, Palaeoecology, (2013). DOI: 10.1016/j.palaeo.2013.01.022

\begin{tabular}{|c|c|c|c|c|c|c|c|c|c|c|c|c|c|c|}
\hline & \multirow{2}{*}{\multicolumn{5}{|c|}{ Taxon name }} & \multicolumn{9}{|c|}{ Samples } \\
\hline & & & & & & \multirow[t]{2}{*}{ S6119a } & \multirow[t]{2}{*}{ S6129a } & \multirow[t]{2}{*}{$\mathrm{s} 6129 \mathrm{~b}$} & \multirow{2}{*}{$\frac{158153}{x}$} & 158155 & 158156 & 158157 & \multirow[t]{2}{*}{158166} & \multirow[t]{2}{*}{158167} \\
\hline 1 & Solenopora & sp. & & algae & & & & & & & & $x$ & & \\
\hline 2 & Epimastopora & sp. & & algae & & $x$ & $x$ & $x$ & & & & $x$ & & \\
\hline 3 & Epimastoporella & sp. & & algae & & & $x$ & $x$ & & $x$ & & $x$ & & \\
\hline 4 & Anchicodium & sp. & & algae & & & & & $x$ & & & & & \\
\hline 5 & Girvanella & sp. & & algae & & & $x$ & & & & & & & \\
\hline 6 & Endotaxis & sp. & & & & & & & & $\mathrm{x}$ & & & & \\
\hline 7 & Tetrataxis & sp. & & & & & & & & & & & & $x$ \\
\hline 8 & Calcivertella & $s p$ & & & & $x$ & & & & & & & $x$ & $x$ \\
\hline 9 & Eostaffella & & ?infulaeformis & Ganelina & 1950 & & & & & & $x$ & & $x$ & $x$ \\
\hline 10 & Eostaffella & & grozdilovae & Maslo and Vachard & & & & & & & & & & $x$ \\
\hline 11 & Eostaffella & & mutabilis & Rauser & 1951 & & & & & & & & $x$ & $x$ \\
\hline 12 & Eostaffella & & lepida & Grozdilova & 1950 & & & & & & & & $x$ & $x$ \\
\hline 13 & Eostaffella & & kashirica rhombo & i Rauser & 1951 & & & & & & $x$ & & $x$ & \\
\hline 14 & Millerella & & & & & & & & & & & & & \\
\hline 15 & Reitlingerina & & timanica & (Rauser) & 1951 & & & & & $x$ & & & & \\
\hline 16 & Reitlingerina & $s p$ & & & & & & $x$ & & $x$ & & & & \\
\hline 17 & Parastaffella & & mathildae & (Dutkevich) & 1934 & & & $x$ & & & $x$ & & & \\
\hline 18 & Bradyina & $s p$ & & & & & & & & & & $x$ & & \\
\hline 19 & Globivalvulina & $\mathrm{sp}$ & & & & $x$ & & & & $x$ & $x$ & $x$ & $x$ & $x$ \\
\hline 20 & Palaeotextularia & $\mathrm{sp}$ & & & & $x$ & & & & & $x$ & $x$ & $\mathrm{x}$ & \\
\hline 21 & Monogenerina & $s p$ & & & & & & & & $x$ & $x$ & $x$ & $x$ & $x$ \\
\hline 22 & Climacammina & $s p$ & & & & & & $x$ & & & & & & \\
\hline 23 & Deckerella & $s p$ & & & & & & & & & $x$ & & & $x$ \\
\hline 24 & Schubertella & & kingi & Dunbar and Skinner & 1937 & & $x$ & & & & & & & \\
\hline 25 & Schubertella & & mjachkovensis & Rauser & 1951 & & & & & & & & $x$ & \\
\hline 26 & Schubertina & sp. & & & & & & & & & & & & \\
\hline 27 & Biwaella & sp. & & & & $x$ & $x$ & $x$ & & & & $x$ & $\mathrm{x}$ & \\
\hline 28 & Biwaella & & shiroshiensis & (Morikawa and Kobaya: & 1963 & $x$ & & & & & & & $x$ & \\
\hline 29 & Biwaella & & poletaevi & Davydov & 2011 & & & $x$ & & & $x$ & & & \\
\hline 30 & Biwaella & & zhikalyaki & Davydov & 2011 & & $x$ & $x$ & & & & $x$ & cf. & \\
\hline 31 & Schellwienia & & modesta & (Scherbovich) & 1971 & & & & & & $x$ & & & \\
\hline 32 & Schwagerina & & gracilis & (Sjomina) & 1971 & $x$ & & $x$ & & $x$ & & $x$ & & \\
\hline 33 & Schwagerina & & vozhgalensis & (Rauser) & 1958 & $x$ & $x$ & $x$ & & $x$ & & & $x$ & \\
\hline 34 & Schwagerina & & subrobusta & (Davydov) & 1986 & $x$ & $x$ & $x$ & & $x$ & $x$ & & $x$ & $x$ \\
\hline 35 & Schellwienia & & klunnikovi & (Davydov) & 1986 & & $x$ & & & $x$ & & $x$ & $x$ & \\
\hline 36 & Schellwienia & & malkovskyi & (Ketat) & 1971 & & $x$ & $x$ & $x$ & & & $x$ & & \\
\hline 37 & Schellwienia & & porrecta & (Sjomina) & 1971 & & $x$ & $x$ & & & & & & \\
\hline 38 & Schwagerina & & pomposa & (Sjomina) & 1961 & & $x$ & $x$ & & & & $x$ & & \\
\hline 39 & Schwagerina & & bianpingensis & (Zhang and Dong) & 1986 & & $x$ & $x$ & & & & $x$ & & \\
\hline 40 & Schwagerina & & timorensis & sp. nov. & & & $x$ & $x$ & & & $x$ & & & \\
\hline 41 & Schwagerina & & maubissensis & sp. nov. & & & $x$ & $x$ & & & $x$ & $x$ & & \\
\hline
\end{tabular}


Figure 1. Position of Timor within the East Gondwana rift system (modified from Harrowfield et al., 2005). Within the interior-rift system, dash lines indicate positions of rifts during final continental breakup (at $155 \mathrm{Ma}$ in the vicinity of Timor; $136 \mathrm{Ma}$ off southwest Australia; Heine and Müller, 2005). Rifting along the Meso-Tethyan ocean boundary started during the Early Permian (Metcalfe, 2006). Paleolatitudes follow Li and Powell (2001). 


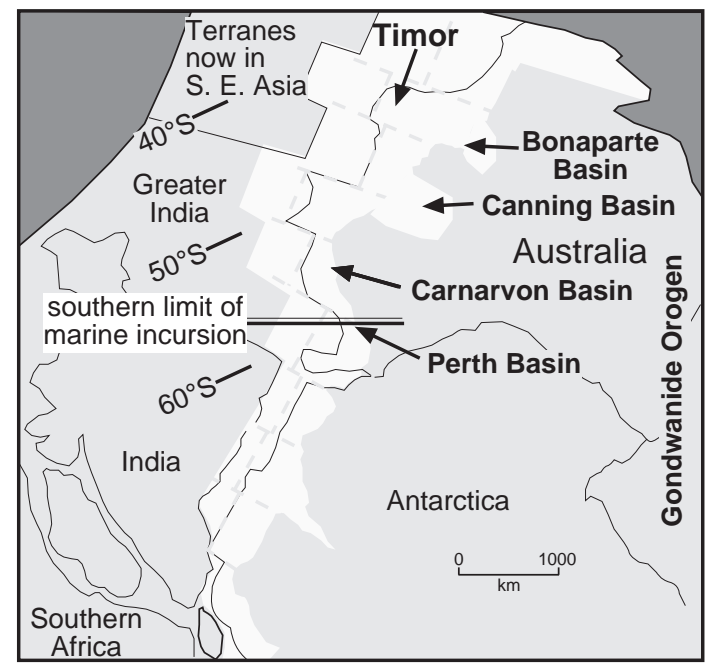

East Gondwana rift system

East Gondwana

Ocean (Meso-Tethys on left) 
Figure 2. STRM image of Timor (compiled from NASA US Shuttle Radar

Topography Mission images) showing the location of the Kulau study site. The insert map shows Timor as part of the non-volcanic Outer Banda Arc. 
NOTICE: this is the author's version of a work that was accepted for publication in Palaeogeography, Palaeoclimatology, Palaeoecology. Changes resulting from the publishing process, such as peer review, editing, corrections, structural formatting, and other quality control mechanisms may not be reflected in this document. Changes may have been made to this work since it was submitted for publication. A definitive version was subsequently published in Palaeogeography, Palaeoclimatology, Palaeoecology, (2013). DOI: 10.1016/j.palaeo.2013.01.022

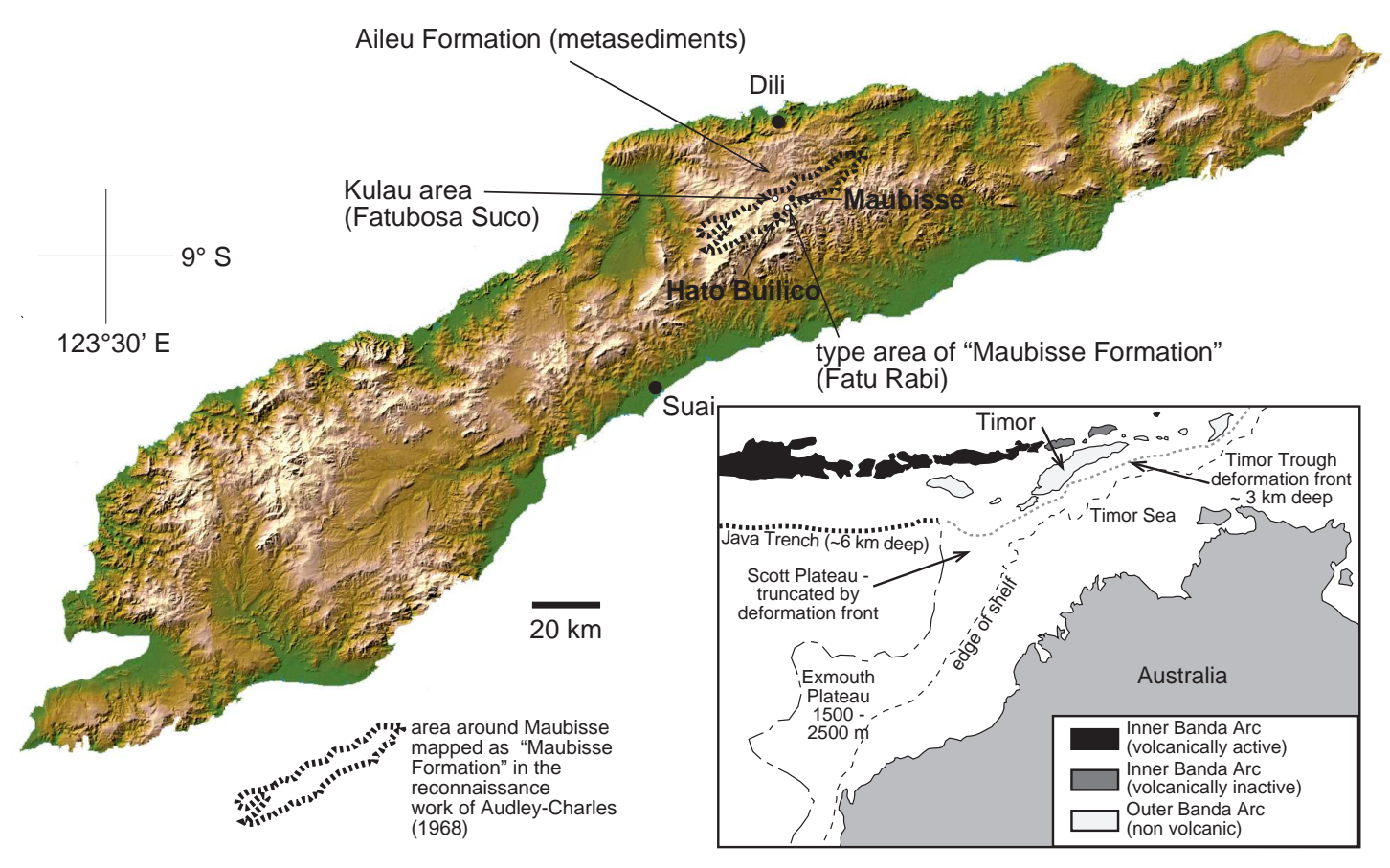


Figure 3. Map of Timor showing extent of Gondwana Megasequence (including the Maubisse Group). Insert image A is an aerial photograph of the Kulau area; image B is an enlarged view showing the extent of the studied bioherm. 
NOTICE: this is the author's version of a work that was accepted for publication in Palaeogeography, Palaeoclimatology, Palaeoecology. Changes resulting from the publishing process, such as peer review, editing, corrections, structural formatting, and other quality control mechanisms may not be reflected in this document. Changes may have been made to this work since it was submitted for publication. A definitive version was subsequently published in Palaeogeography, Palaeoclimatology, Palaeoecology, (2013). DOI: 10.1016/j.palaeo.2013.01.022

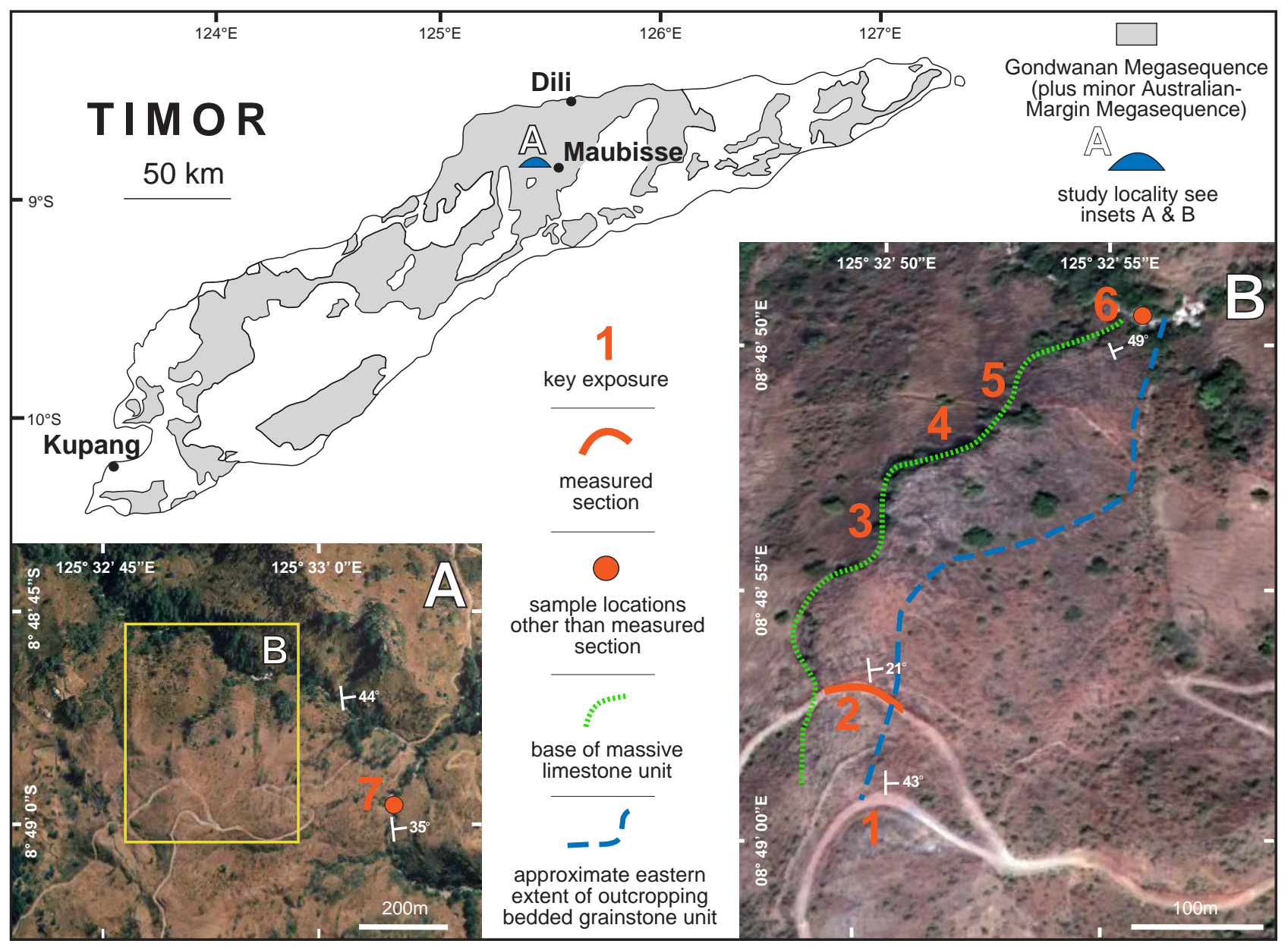


Figure 4. Stratigraphic log of the studied bioherm. 
NOTICE: this is the author's version of a work that was accepted for publication in Palaeogeography, Palaeoclimatology, Palaeoecology. Changes resulting from the publishing process, such as peer review, editing, corrections, structural formatting, and other quality control mechanisms may not be reflected in this document. Changes may have been made to this work since it was submitted for publication. A definitive version was subsequently published in Palaeogeography, Palaeoclimatology, Palaeoecology, (2013). DOI: 10.1016/j.palaeo.2013.01.022

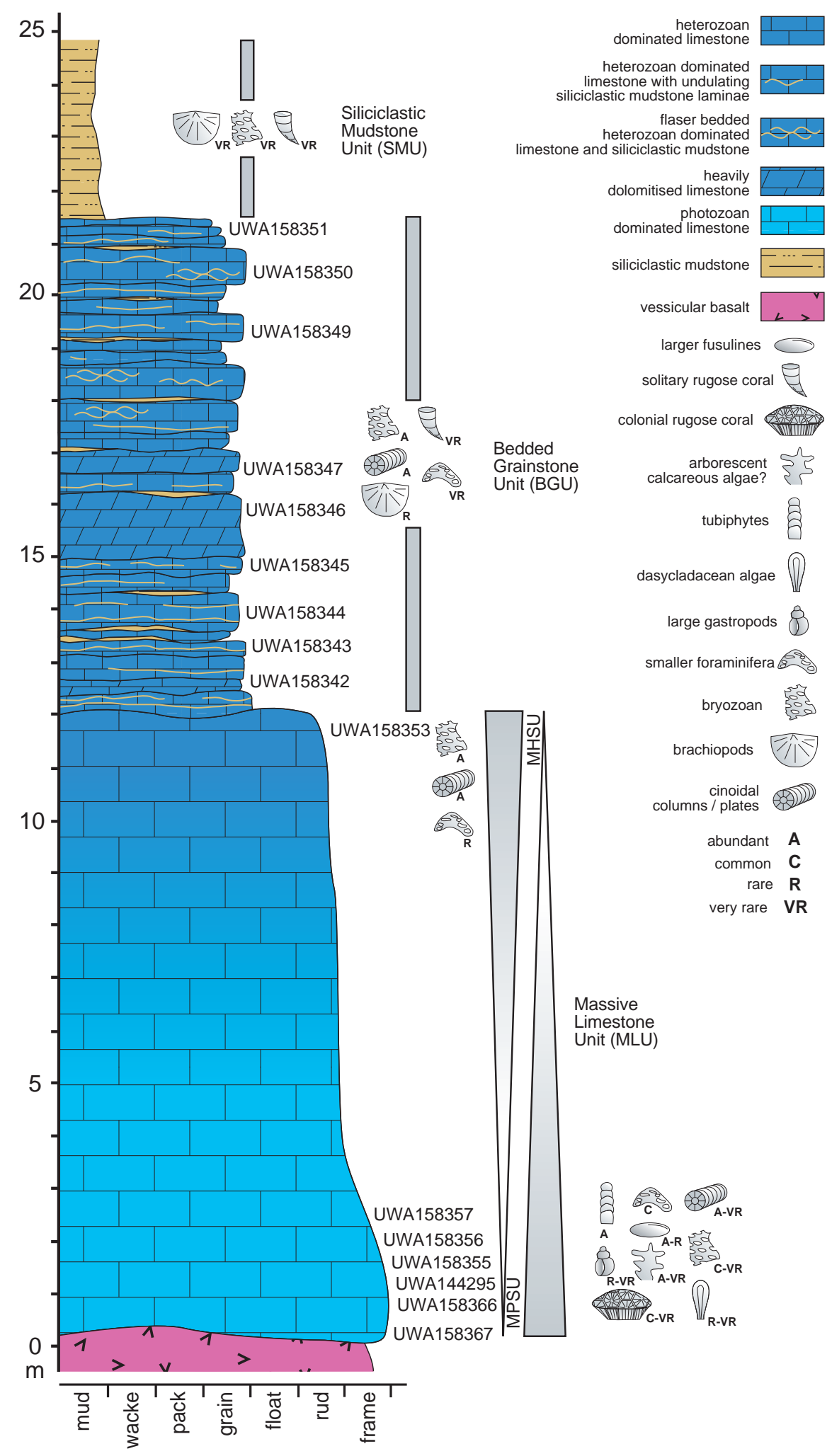


Figure 5. Massive limestone unit (MLU). A, contact between vesicular basalt and overlying reef-framework limestone (MPSU), locality 6. B, lowest part of MLU, showing framework of aborescent algae(?) and colonial rugose corals (MPSU), locality 6. C, lower part of MLU showing large gastropods and coral fragments with a framework of arborescent algae(?) (MPSU), locality 6. D, lower part of MLU showing branching corallum with large diameter corallites (MPSU), locality 6. E, cliff section at locality 4 with massive limestone unit (MLU) overlain by bedded grainstone unit (BGU). F, massive limestone unit at locality 2 showing karstic weathering. G. base of massive limestone unit at locality 6 showing "lens" of limestone within basalt below the main contact with MLU where person is sitting. 
NOTICE: this is the author's version of a work that was accepted for publication in Palaeogeography, Palaeoclimatology, Palaeoecology. Changes resulting from the publishing process, such as peer review, editing, corrections, structural formatting, and other quality control mechanisms may not be reflected in this document. Changes may have been made to this work since it was submitted for publication. A definitive version was subsequently published in Palaeogeography, Palaeoclimatology, Palaeoecology, (2013). DOI: 10.1016/j.palaeo.2013.01.022
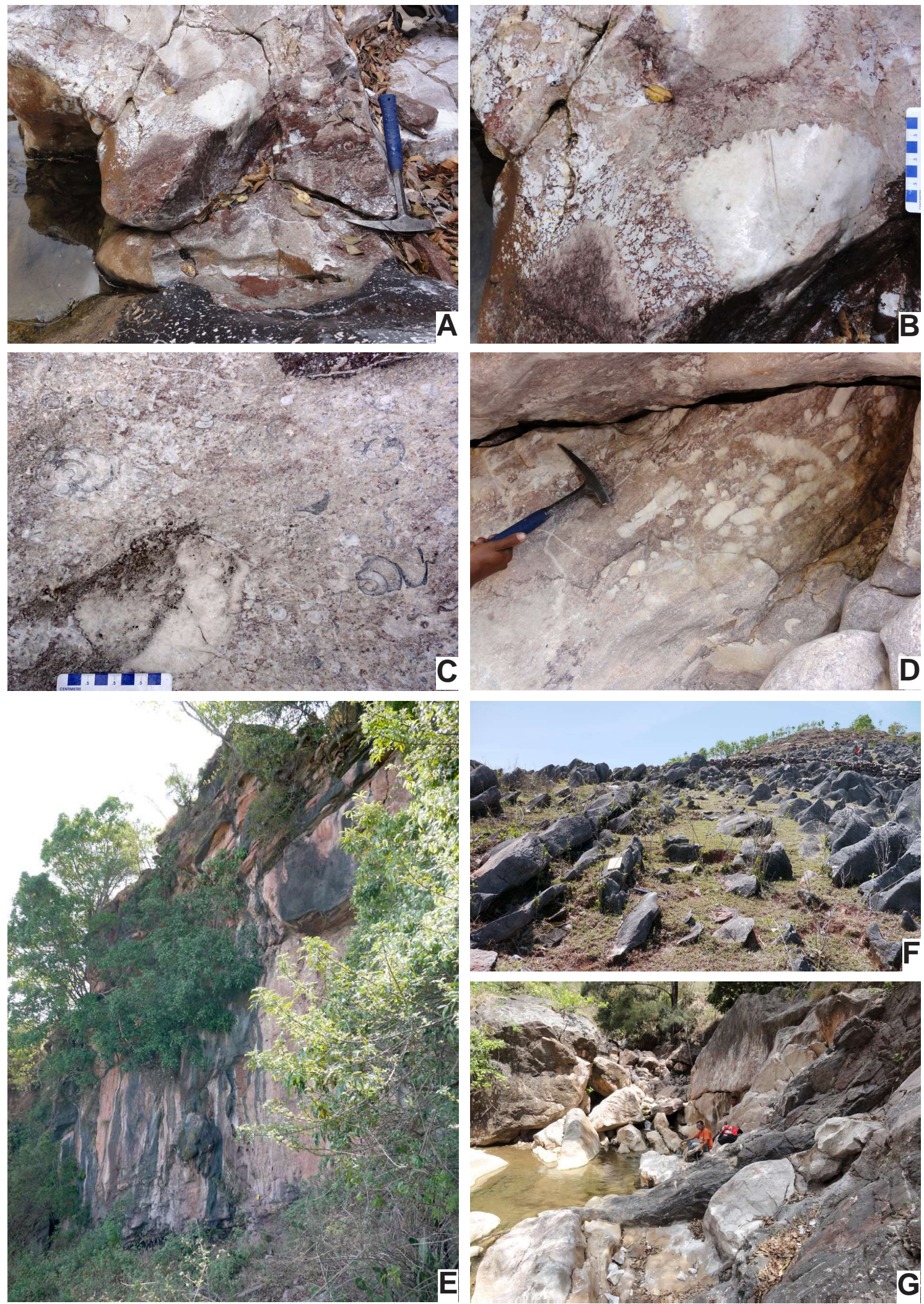
Figure 6. Bedded grainstone unit (BGU). A, BGU in river at locality 6. B, Enlarged view of outcrop at locality 6 showing bedding pattern. C. Cliff face outcrop at locality 5 showing lower beds of BGU. D, BGU at locality 2 showing interbedded friable red mudstone. 
NOTICE: this is the author's version of a work that was accepted for publication in Palaeogeography, Palaeoclimatology, Palaeoecology. Changes resulting from the publishing process, such as peer review, editing, corrections, structural formatting, and other quality control mechanisms may not be reflected in this document. Changes may have been made to this work since it was submitted for publication. A definitive version was subsequently published in Palaeogeography, Palaeoclimatology, Palaeoecology, (2013). DOI: 10.1016/j.palaeo.2013.01.022
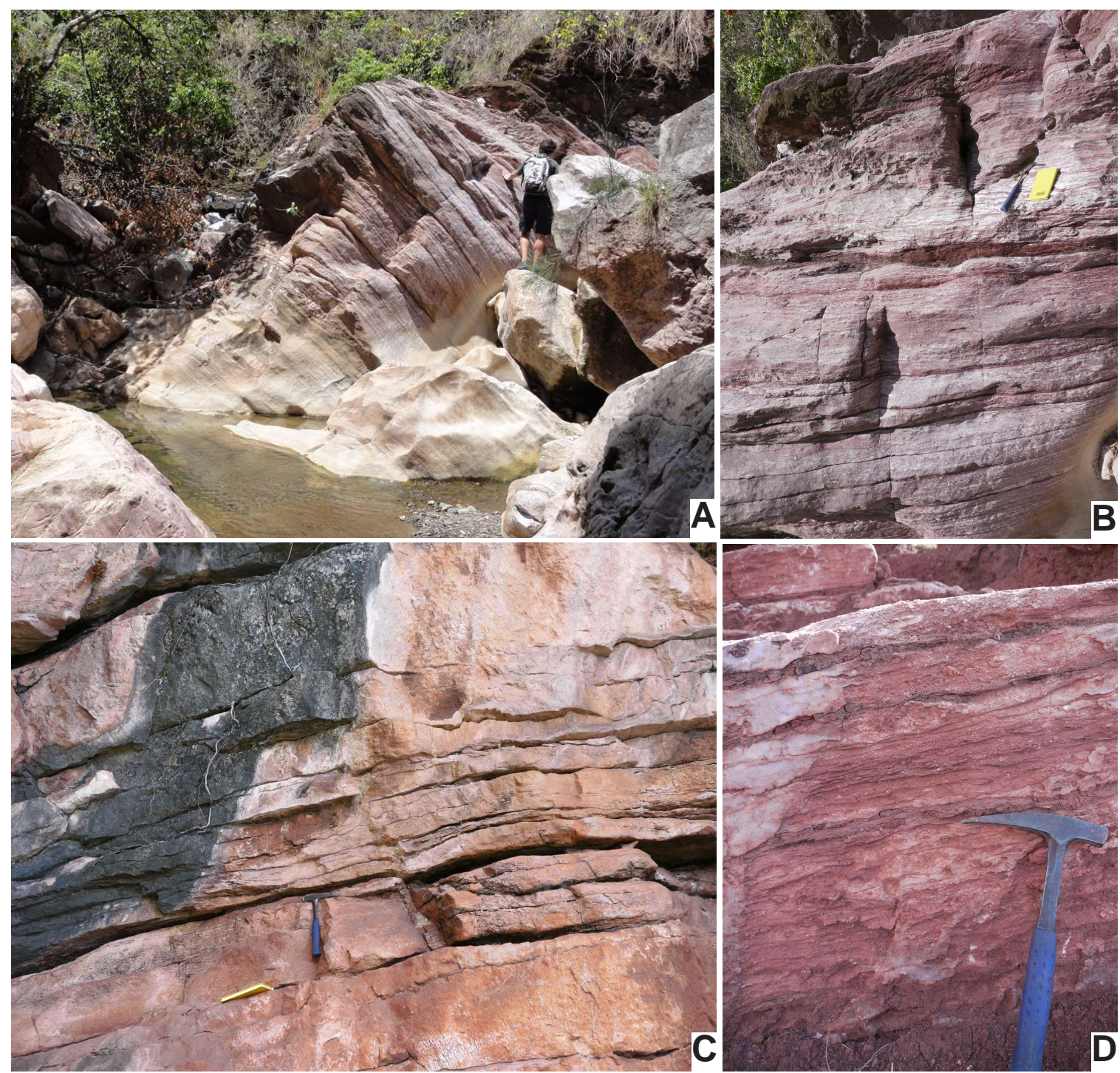
Figure 7. Correlation chart comparing the Timor succession with units known further south in the East Gondwana rift system. In Timor, the stratigraphy above the Gzhelian is schematic with precise positions of bioherms, bedded limestone and volcaniclastic units uncertain. In the Bonaparte, Canning, Southern Carnarvon, and Northern Perth Basins, the ages of the lower parts of the Kulshill Group, Grant Group, Lyons Group, and Nangetty Formation are uncertain but may range down into the Gzhelian (see discussion in 6.3) 
NOTICE: this is the author's version of a work that was accepted for publication in Palaeogeography, Palaeoclimatology, Palaeoecology. Changes resulting from the publishing process, such as peer review, editing, corrections, structural formatting, and other quality control mechanisms may not be reflected in this document. Changes may have been made to this work since it was submitted for publication. A definitive version was subsequently published in Palaeogeography, Palaeoclimatology, Palaeoecology, (2013). DOI: 10.1016/j.palaeo.2013.01.022

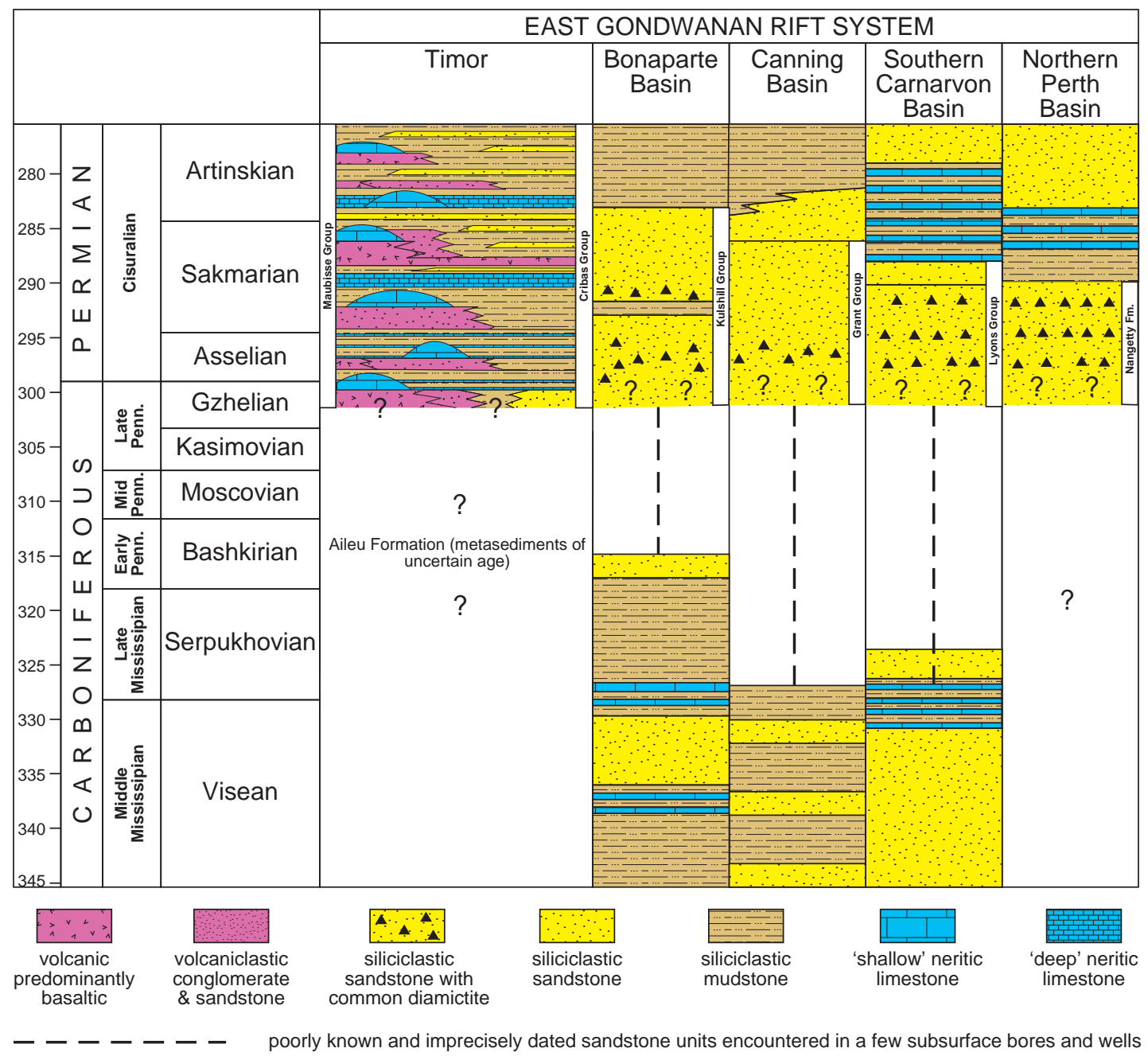





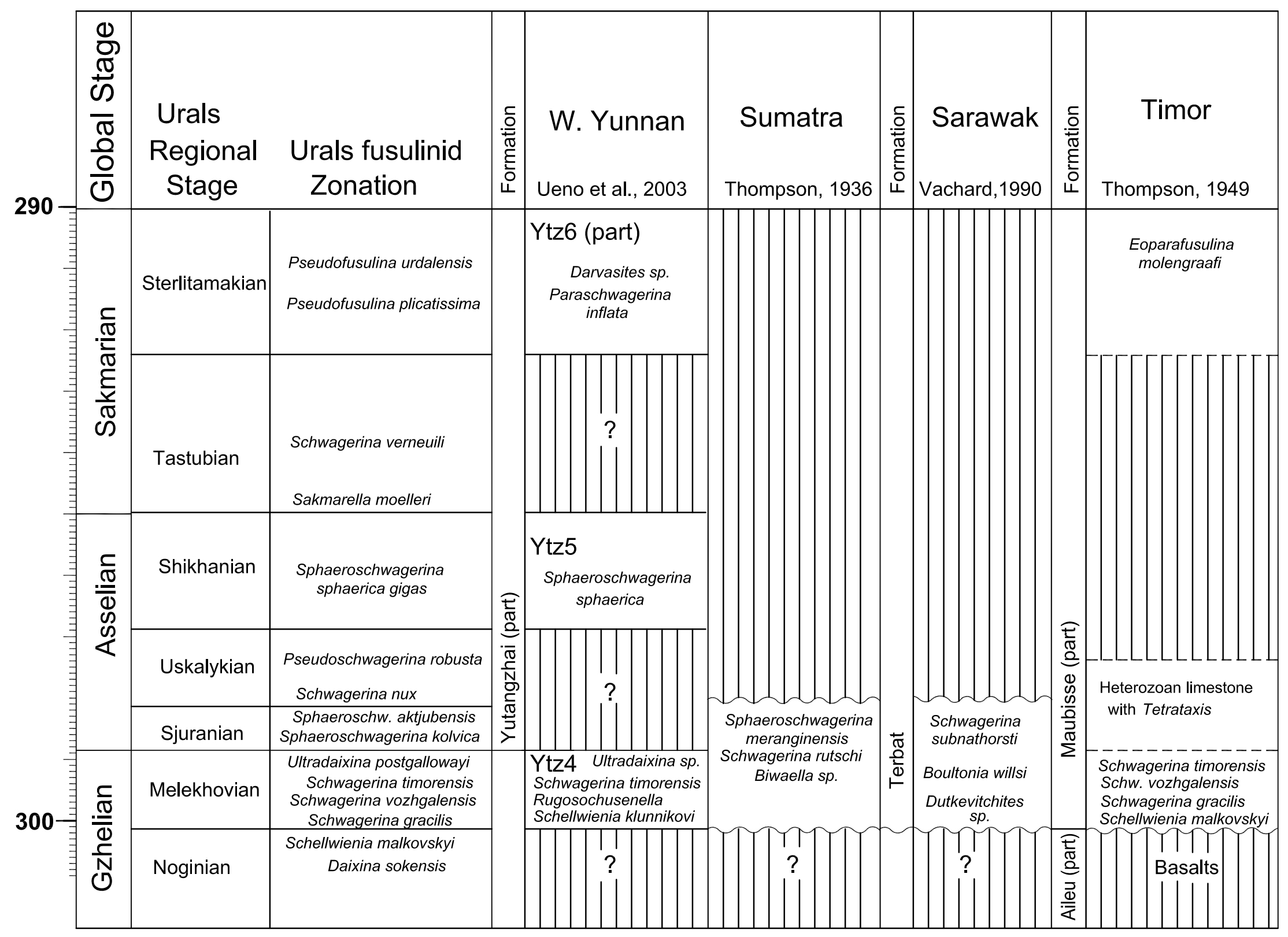

